http://kitaibelia.unideb.hu/

ISSN 2064-4507 (Online) • ISSN 1219-9672 (Print)

(C) Department of Botany, University of Debrecen, Hungary

26(1): 49-76.; 2021

DOI: $10.17542 /$ kit.26.49

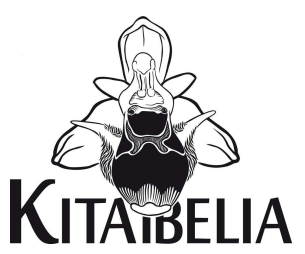

\title{
A Duna-Tisza köze gyertyános-tölgyesei (Convallario-Carpinetum Kevey 2008)
}

\author{
KEveY Balázs \\ Pécsi Tudományegyetem, Ökológiai Tanszék, H-7624 Pécs, Ifjúság u. 6.; keveyb@gamma.ttk.pte.hu

\section{Forests of the sand-hill region of the Danube-Tisza Interfluve (Convallario-Carpinetum Kevey 2008)}

\begin{abstract}
The heavily fragmented and isolated pedunculate oak-hornbeam forests are remnants of the natural vegetation of the sand dune area of the Danube-Tisza Interfluve, where they are found mostly in interdunal depressions. To determine their main phytosociological characteristics, we collected and analyzed data from 25 stands. The results show that these forests are the most similar in species composition to the oak-hornbeam forests (Convallario-Carpinetum Kevey 2008) described from the Nyírség.
\end{abstract}

Keywords: closed oak forests on sand, Middle Hungary, Syntaxonomy

Összefoglalás - Jelen tanulmány 25 cönológiai felvétellel mutatja be a Duna-Tisza köze homoki gyertyános-tölgyeseinek társulási viszonyait. Erősen fragmentált és izolált állományai a homokhátak mélyedéseiben, horpadásaiban fordulnak elő. Faji összetételük a hagyományos és sokváltozós statisztikai elemzési eredmények szerint a Nyírségből leírt homoki gyertyános-tölgyesekkel (ConvallarioCarpinetum Kevey 2008) azonosíthatók.

Kulcsszavak: Közép-Magyarország, szüntaxonómia, zárt homoki tölgyes

\section{Bevezetés}

A gyertyánt a Duna-Tisza köze homokvidékéről először FRIVALDSZKY (1859) említette a Peszéri-erdőből (Kunpeszér). A gyertyános-tölgyesre mint erdőtársulásra először BoRos $(1935 a, 1935 b)$ hívta fel a figyelmet, aki Csévharaszt mellől a pótharaszti Nagy-erdőből említett egy nagyrészt gyertyánból álló erdőrészt. Ennek maradványait kérésemre Hajdu Oszkár erdész mutatta meg. BABOS (1954) és TóTH (1973) a kunbaracsi gyertyános-tölgyesről közölt egy rövid jellemzést. Megkeresésében Molnár Zsolt és Vadász Csaba volt segítségemre. Kunadacs határában Vadász Csaba több kisebb gyertyános-tölgyes foltot mutatott, míg Kunfehértónál Csiky János, Szentmártonkátánál pedig Urbán Sándor hívta fel figyelmemet egy-egy kicsiny állományra. CsÁKY (2018) az ócsai erdő több részletéből is említi a gyertyánt. Társulást alkotó állományait 2015-ben végzett terepbejárásaim során megtaláltam. CsÁKY (2018) a táborfalvai lőtér északkeleti határáról is említ egy gyertyán állományt. Valószínűleg ezt a gyertyános-tölgyes foltot találtam meg 2012-ben Lendvai Gábor kollégámmal, s a lelőhelyet egy térkép segítségével a „Göböly-erdő”-vel azonosítottuk. E maradvány jellegű gyertyánostölgyesekből 25 cönológiai felvételt sikerült készítenem. 


\section{Anyag és módszer}

Kutatási terület jellemzése

A vizsgált gyertyános-tölgyesek BoRHIDI (1961) klímazonális térképe szerint az erdőssztyepp zónában foglalnak helyet, ezért extrazonálisnak tekinthetők. A Duna-Tisza köze - főleg északi részének - egykor terjedelmesebb homoki erdei (BIRó 2008, BIRó \& MolnÁr 2009, BALCZó et al. 2011) az erdőirtások és a kultúrerdők (főleg telepített feketefenyvesek és akácosok) térhódítása miatt mára parányi állományokká zsugorodtak. Ezen maradványerdők között ma már csak elvétve találhatók gyertyános-tölgyesek, s azok is többnyire elszegényedett, kicsiny foltokat képeznek a gyöngyvirágos-tölgyesek (Polygonato latifolio-Quercetum roboris) és a kultúrerdők (főleg akácosok, valamint feketefenyő és erdeifenyő) közötti kisebb mélyedésekben, horpadásokban. Ezek a maradványfoltok 100 és 142 m közötti tengerszint feletti magasság mellett találhatók. Az alapkőzetet könnyen kiszáradó, meszes homok képezi, amelyen barna erdőtalaj alakult ki. Mikroklímájuk mérsékelten hűvös, párás, talajuk az üde vízgazdálkodási fokozatba sorolható.

Alkalmazott módszerek

A cönológiai felvételeket a Zürich-Montpellier növénycönológiai iskola (BECKING 1957, BRAUN-BLANQUET 1964) hagyományos kvadrát-módszerével készítettem. A felvételek táblázatos összeállítását, valamint a karakterfajok csoportrészesedését és csoporttömegét az „NS” számítógépes programcsomag (KEVEY \& HIRMANN 2002) segítségével végeztem. A felvételkészítés és a hagyományos statisztikai számítások módszere korábbi dolgozatomban (KEVEY 2008) megtalálható. Az asszociációk összehasonlításánál - a SYN-TAX 2000 programcsomag (PoDANI 2001) segítségével bináris adatokon alapuló hierarchikus osztályozást, clusteranalízist (hasonlósági index: Baroni-Urbani-Buser; osztályozó módszer: teljes lánc), és szintén bináris alapú ordinációt (hasonlósági index: Baroni-Urbani-Buser; ordinációs módszer: főkoordináta-analízis) végeztem. A fajok esetében HoRvÁTH et al. (1995), a társulásoknál pedig az újabb hazai nómenklatúrát (BoRHIDI \& KEVEY 1996, KEVEY 2008, BoRHIDI et al. 2012) követem. A társulástani és a karakterfaj-statisztikai táblázatok felépítése az újabb eredményekkel (OBERDORFER 1992, MuCinA et al. 1993, KEVEY 2008, BoRHIDI et al. 2012) módosított Soó (1980) féle cönológiai rendszerre épül. A növények cönoszisztematikai besorolásánál is elsősorban Soó $(1964,1966,1968,1970,1973,1980)$ Synopsis-ára támaszkodtam, de figyelembe vettem az újabb kutatási eredményeket is (vö. BoRHIDI 1993, 1995, HoRvÁTH et al. 1995, KEVEY 2008).

\section{Eredmények}

Fiziognómia

A felső lombkoronaszint közepesen, vagy erősebben zárt, 65-85\% borítást mutat, magassága pedig az állomány korától függően 22-32 méter. Az átlagos törzsátmérő ennek megfelelően 40 és $70 \mathrm{~cm}$ között változik. Állandó (K: IV-V) fái a Carpinus betulus és a Quercus robur. Rajtuk kívül néhol a Fraxinus angustifolia is előfordulhat nagyobb tömegben (A-D: 3-5). Az alsó lombkoronaszint igen változó. Borítása 20-70\%, magassága pedig 15-22 m. Állandó (K: IVV) fája csak a Carpinus betulus, amely nagyobb tömeget (A-D: 3-4) is képezhet. Jellemző to- 
vábbá egyes cserjék fatermetű példányainak (Cornus sanguinea, Corylus avellana, Crataegus monogyna, Rhamnus catharticus) és egyes liánok (Hedera helix, Vitis sylvestris) megjelenése.

A cserjeszint szintén változóan fejlett, amely valószínúleg az erdészeti kezeléssel kapcsolatos. Borítása 5-60\%, magassága pedig 2-3,5 m. Állandó (K IV-V) fajai a Carpinus betulus, a Cornus sanguinea, a Crataegus monogyna és a Ligustrum vulgare. Jelentősebb tömeget (A-D: 3) csak a Fraxinus angustifolia ér el. Az újulat fejlettsége is igen változó, borítása 1-75\%. Állandó (K: IV-V) fajai az alábbiak: Carpinus betulus, Crataegus monogyna, Euonymus europaeus, Fraxinus angustifolia, Ligustrum vulgare, Quercus robur, Rhamnus catharticus, Rubus caesius, Sambucus nigra. E szintben nagyobb tömeget (A-D: 4) csak a Hedera helix képez.

A gyepszint szintén változóan fejlett, borítása 5-60\%. Állandó (K: IV-V) fajai a következők: Alliaria petiolata, Brachypodium sylvaticum, Convallaria majalis, Cucubalus baccifer, Dactylis polygama, Elymus caninus, Fallopia dumetorum, Galium aparine, Geranium robertianum, Geum urbanum, Polygonatum latifolium, Stellaria media, Veronica sublobata. Fácies képző (AD: 3) szerepet csak a Polygonatum latifolium tölt be (vö. 1. táblázat).

\section{Fajkombináció \\ Állandósági osztályok}

A 25 cönológiai felvétel alapján a vizsgált homoki gyertyános-tölgyesekből 13 konstans (K V) és 10 szubkonstans (K IV) faj szerepel az alábbiak szerint: - K V: Alliaria petiolata, Brachypodium sylvaticum, Carpinus betulus, Cornus sanguinea, Crataegus monogyna, Dactylis polygama, Euonymus europaeus, Fraxinus angustifolia, Galium aparine, Geum urbanum, Ligustrum vulgare, Polygonatum latifolium, Quercus robur. - K IV: Celtis occidentalis, Convallaria majalis, Cucubalus baccifer, Elymus caninus, Fallopia dumetorum, Geranium robertianum, Rhamnus catharticus, Rubus caesius, Stellaria media, Veronica sublobata. A felvételi anyagban ezen kívül 19 akcesszórikus (K III), 24 szubakcesszórikus (K II) és 109 akcidens (K I) faj is szerepel. Az állandósági osztályok fajszáma tehát az akcidenstől (K I) a szubkonstans elemekig csökken, majd a konstans fajoknál ismét kissé magasabb (vö. 1.ábra; 1. táblázat).

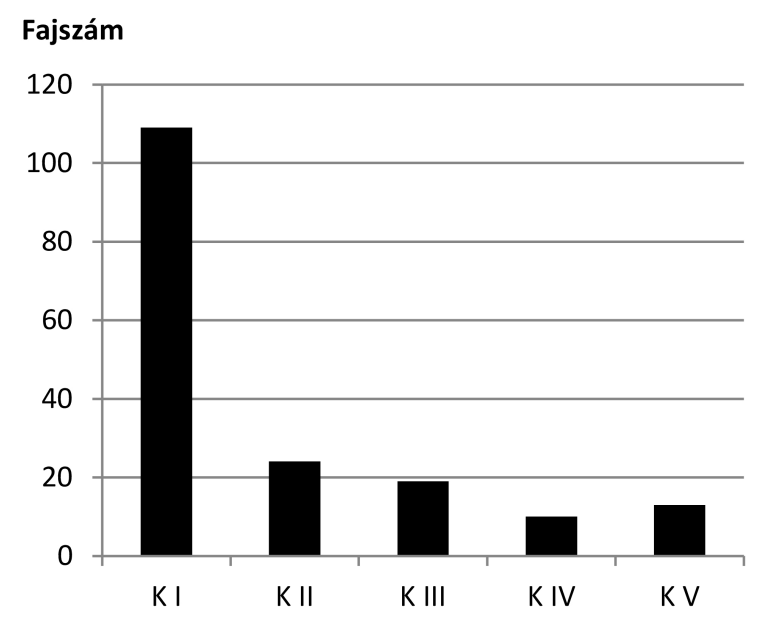

1. ábra Az állandósági osztályok eloszlása Fig. 1 Distribution of constancy classes 
Kitaibelia 26(1): 49-76.
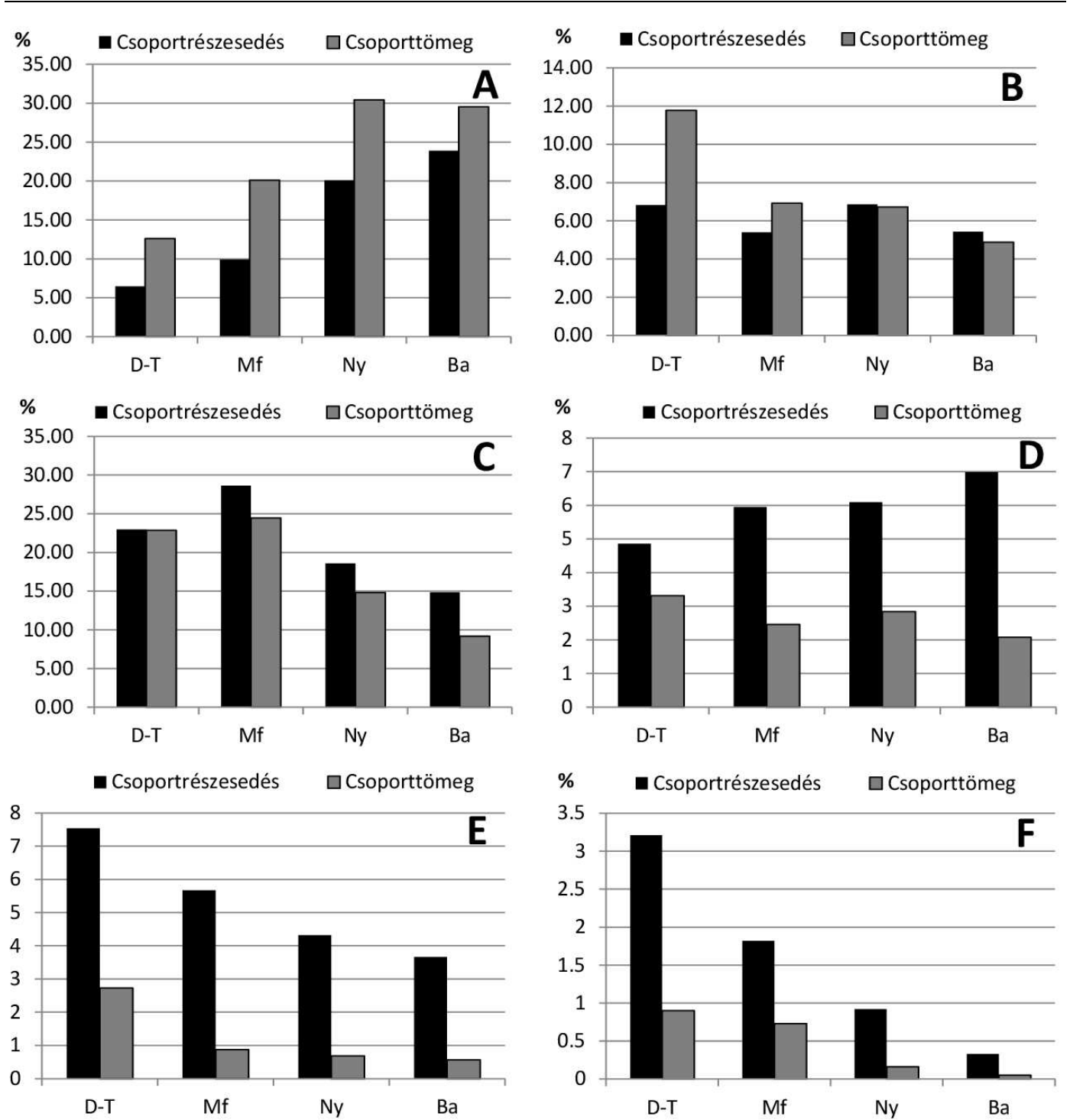

2. ábra A Fagetalia fajok aránya; B Alnion incanae fajok aránya; C Quercetea pubescentis-petraeae fajok aránya; D Specialisták (S 6) aránya; E Természetes gyomok (W 1) aránya; F Agresszív tájidegen inváziós fajok (AC -3) aránya

Fig. 2 A Proportion of species characteristic of the order Fagetalia; B Proportion of species characteristic of the alliance Alnion incanae s.l.; C Proportion of species characteristic of the class Quercetea pubescentis-petraeae s.l.; D Proportion of specialist species (S 6); E Proportion of weed species (W 1); F Proportion of aggressive competitor species (AC -3)

D-T: Duna-Tisza köze (Kevey ined.: 25 felv.); Mf: Mezőföld (Kevey \& Lendval 2015: 25 felv.); Ny: Nyírség (Kevey et al. 2017: 25 felv.); Ba: Bakonyalja (Kevey 2014: 10 felv.)

\section{Karakterfajok aránya}

A gyertyános-tölgyesek felépítésében jelentősebb szerepet töltenek be a mezofil lomberdei elemek. E Fagetalia jellegü fajok 6,46\% csoportrészesedést és 12,60\% csoporttömeget érnek 
el. A négy homokvidék közül a Duna-Tisza közén mutatják a legkisebb arányt (5. táblázat, 2. ábra A). Hasonló gyakoriságban fordulnak elő a keményfaligeti növények (Alnion incanae) 6,82\% csoportrészesedéssel és 11,78\% csoporttömeggel. Arányuk a Duna-Tisza közén a legmagasabb (5. táblázat, 2. ábra B). Sokkal nagyobb mennyiségben vannak képviselve a száraz tölgyesek elemei, a Quercetea pubescentis-petraeae s.l. jellegű fajok is, amelyek 22,98\% csoportrészesedést és 22,86\% csoporttömeget érnek el. Arányuk magasabb, mint a Nyírségben és a Bakonyalján, s kissé alacsonyabb, mint a Mezőföldön (5. táblázat, 2. ábra C).

\section{Szociális magatartási típusok aránya}

A specialisták (S 6) csoportrészesedése a négy homoki gyertyános-tölgyes közül a DunaTisza közén a legalacsonyabb (6. táblázat, 2. ábra D). Ezzel szemben a természetes gyomok (W 1) és az agresszív tájidegen inváziós fajok (AC -3) aránya a Duna-Tisza közén a legmagasabb (6. táblázat, 2. ábra E-F). Ezen értékekkel kapcsolatos, hogy a homoki gyertyánostölgyesek közül a Duna-Tisza közi állományok természetességi értéke a legkisebb (6. táblázat).

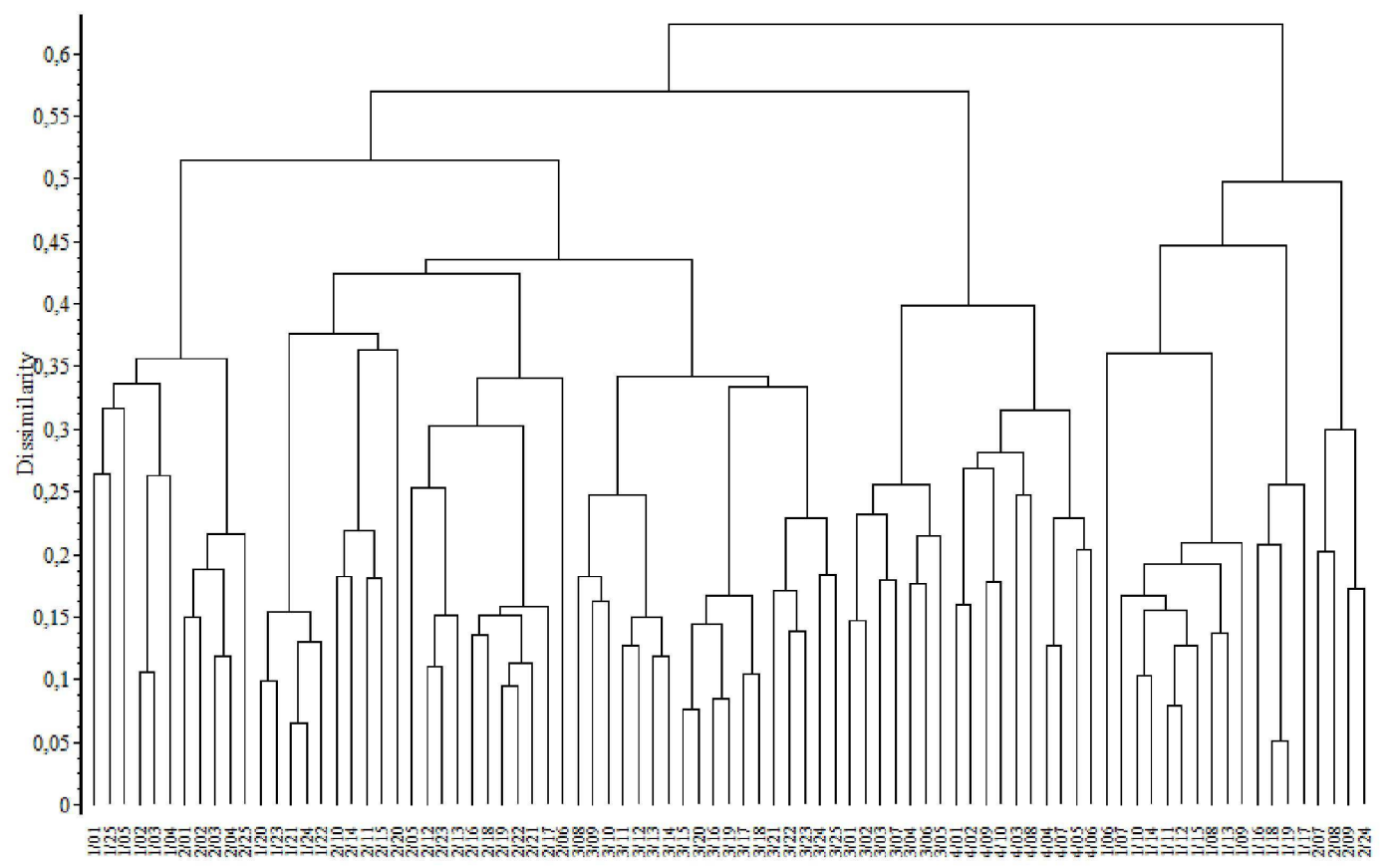

3. ábra Cönológiai felvételek bináris dendrogramja (hasonlósági index: Baroni-Urbani - Buser; osztályozó módszer: teljes lánc)

Fig. 3 Binary dendrogram of the relevés

(similarity coefficient: Baroni-Urbani - Buser; clustering method: complete link)

1/1-25: Duna-Tisza köze (KeveY ined.: 25 felv.)

2/1-25: Mezőföld (KeveY \& LeNDVAI 2015: 25 felv.)

3/1-25: Nyírség (KeveY et al. 2017: 25 felv.)

4/1-10: Bakonyalja (KEVEY 2014: 10 felv.) 


\section{Sokváltozós elemzések eredményei}

A Duna-Tisza köze gyertyános-tölgyeseit (Convallario-Carpinetum) bináris cluster-analízis és ordináció révén hasonlítottam össze egyéb alföldi (Mezőföld, Nyírség), ill. síkvidéki jellegű (Bakonyalja) tájak homoki gyertyános-tölgyeseivel. A dendrogramon (3. ábra) és az ordinációs diagramokon (4. ábra) e különböző tájak felvételei nem különülnek el egyértelműen. Leginkább a Duna-Tisza köze és a Mezőföld felvételei keverednek, de némi átfedés mutatkozik a Nyírség és a Bakonyalja felvételei között is.

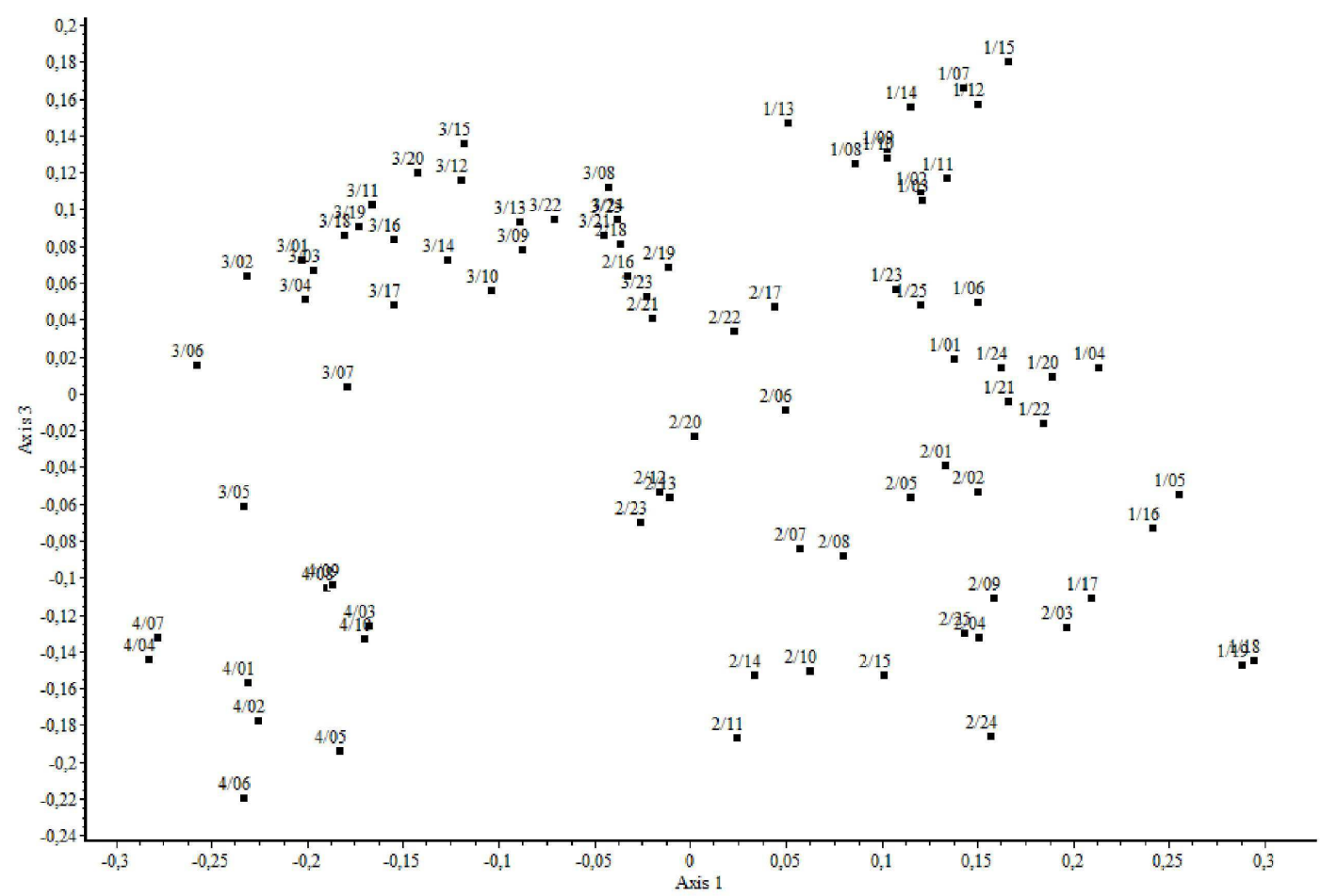

4. ábra Cönológiai felvételek bináris ordinációs diagramja

(hasonlósági index: Baroni-Urbani - Buser; ordinációs módszer: főkoordináta analízis)

Fig. 4 Binary ordination diagram of the relevés.

(similariti coefficient: Baroni-Urbani-Buser; ordination method: principal coordinates analysis)

1/1-25: Duna-Tisza köze (KeveY ined.: 25 felv.)

2/1-25: Mezőföld (KeVEY \& LENDVAI 2015: 25 felv.)

3/1-25: Nyírség (Kevey et al. 2017: 25 felv.)

4/1-10: Bakonyalja (KEVEY 2014: 10 felv.)

\section{Természetvédelmi vonatkozások}

A töredékes homoki gyertyános-tölgyesek (Convallario-Carpinetum) - annak ellenére, hogy állományai többé-kevéssé bolygatottak - a Duna-Tisza köze vegetációjának értékes mozaikjait képezik. Állományai mára erősen megritkultak, ezért természetvédelmi szempontból különös odafigyelést érdemelnek. Turján-vidéki állományai az Ócsai Tájvédelmi Körzet részét képezik. A Kunfehértói „Holdrutás-erdő” ma már országos jelentőségű Természetvédel- 
mi Terület, míg a Kunbaracsi gyertyános-tölgyes helyi védelem alatt áll. Sajnos a többi gyertyános-tölgyes mindeddig nem részesült védelemben.

A vizsgált homoki gyertyános-tölgyesekből hét védett (Cephalanthera damasonium, Doronicum hungaricum, Epipactis helleborine, Epipactis microphylla, Listera ovata, Veratrum album, Vitis sylvestris) és egy fokozottan védett (Botrychium virginianum) növényfaj került elő. Különösen utóbbi faj előfordulása jelentős, ugyanis magyarországon egyetlen lelőhelye itt található. E növények tovább emelik a homoki gyertyános-tölgyesek természetvédelmi értékét.

Az asszociáció dendrológiai értékeihez tartoznak egyes fává nőtt cserjék (Cornus sanguinea, Corylus avellana, Crataegus monogyna, Rhamnus catharticus). A Corylus és Crataegus egyedek között akadnak $40 \mathrm{~cm}$ törzsátmérőt is elérő példányok.

Flóraszennyező hatást fejtenek ki a felvételekben is szereplő egyes adventív növényfajok: K IV: Celtis occidentalis. - K III: Robinia pseudo-acacia. - K II: Padus serotina. - K I: Acer negundo, Aesculus hippocastanum, Ailanthus altissima, Asclepias syriaca, Fraxinus pennsylvanica, Gleditsia triacanthos, Impatiens parviflora, Juglans nigra, Morus alba, Phytolacca americana, Quercus rubra, Solidago canadensis, Solidago gigantea, Syringa vulgaris. A területen különösen aggasztó a Celtis occidentalis, a Padus serotina és a Robinia pseudo-acacia agresszív terjeszkedése. Jelen helyzetben ezek visszaszorítására nincs hatékony megoldás.

E homoki gyertyános-tölgyesek hosszú távú megőrzése érdekében elsősorban az erdőgazdálkodási beavatkozásokon kell változtatni, így meg kell szüntetni a homokvidékeken gyakran alkalmazott, élővilágra nézve kíméletlen módszereket (tarvágás, tuskóírtás, mélyszántás, vegyszerezés, idegenhonos fafajok telepítése), nehogy a jelenkort megért néhány állomány is a kultúrerdők áldozatává váljon (telepített erdeifenyvesek, akácosok, fekete dió ültetvények). Sajnos erre rossz példát tudok említeni. Néhány éve a szentmártonkátai állomány megsemmisült. A tulajdonos ugyanis a kicsiny gyertyános-tölgyes foltot körülkeríttette, s a kerítésen belül nagy létszámú - főleg kérődzőkből álló - állatállományt tart. Az aljnövényzet a taposási, rágási és trágyázási károsítástól felismerhetetlenné degradálódott.

\section{Eredmények megvitatása}

A Duna-Tisza köze gyertyános-tölgyesei ma már erősen fragmentráltak és izoláltak. Állományainak jelentős részén az elszegényedés jelei mutatkoznak. Viszonylag természetszerűnek tûnnek az ócsai és a kunbaracsi felvételek. Ennek ellenére komplex faji összetételük lényegesen nem különbözik az egyéb (Bakonyalja, Mezőföld, Nyírség) homoki gyertyánostölgyesekétől (3-4. ábra). A karakterfajok tekintetében a mezőföldi gyertyános-tölgyesekhez (KEVEY \& LENDVAI 2015) állnak a legközelebb, így bennük igen alacsony a Fagetalia és magas a Quercetea pubescentis-petraeae elemek aránya, amelyek a Bakonyalján és a Nyírségben jóval magasabb, ill. alacsonyabb értékeket mutatnak (5. táblázat, 2. ábra A és C). Ezen adatok összefüggésbe hozhatók azzal, hogy amíg a Duna-Tisza köze és a Mezőföld az erdőssztyep zónában foglal helyet, addig a Bakonyalja és a Nyírség már a csapadékosabb zárt tölgyes zónába sorolható (vö. BORHIDI 1961).

A sokváltozós eredmények szerint a Nyírség, a Mezőföld, a Nyírség és a Bakonyalja homoki gyertyános-tölgyesei egymástól nem különültek el lényegesen (3-4. ábra). Mindez arra enged következtetni, hogy a négy táj vizsgált állományai egyetlen asszociációhoz sorolhatók. Ennek megfelelően a Duna-Tisza köze gyertyános-tölgyeseit a Nyírségből leírt ConvallarioCarpinetum-mal (KEVEY 2008) azonosíthatjuk, mint annak Duna-Tisza közi, fajszegényebb változatát. Cönoszisztematikai helye az alábbi módon vázolható: 
Divisio: Q U E R C O - F A G E A Jakucs 1967

Classis: QUERCO-FAGETEA Br.-Bl. et Vlieger in Vlieger 1937 em. Borhidi in Borhidi et Kevey 1996

Ordo: FAGETALIA SYLVATICAE Pawłowski in Pawłowski et al. 1928

Alliance: Fagion sylvaticae Luquet 1926

Suballiance: Carpinenion betuli Issler 1931

Associatio: Convallario-Carpinetum Kevey 2008

Itt tennék említést e homoki gyertyános-tölgyesek őshonosságának kérdéséről. BABOS (1954) szerint a kunbaracsi állomány őshonossága „esetleg a szubboreális korig is visszavezethető". A Peszéri-erdőből FRIVALDSZKY (1859) közli. Bár előfordulását KERNER (1867) inkább ültetettnek tekinti, CSÁKY (2018) szerint több érv is szól az őshonossága mellett. A többi lelőhely őshonosságát valószínűsíti az, hogy mintegy 100 évvel ezelőtt nemhogy nem telepítették a gyertyánt, hanem inkább az eltávolítandó fafajok közé tartozott (BunD 1921, CSÁKY 2018).

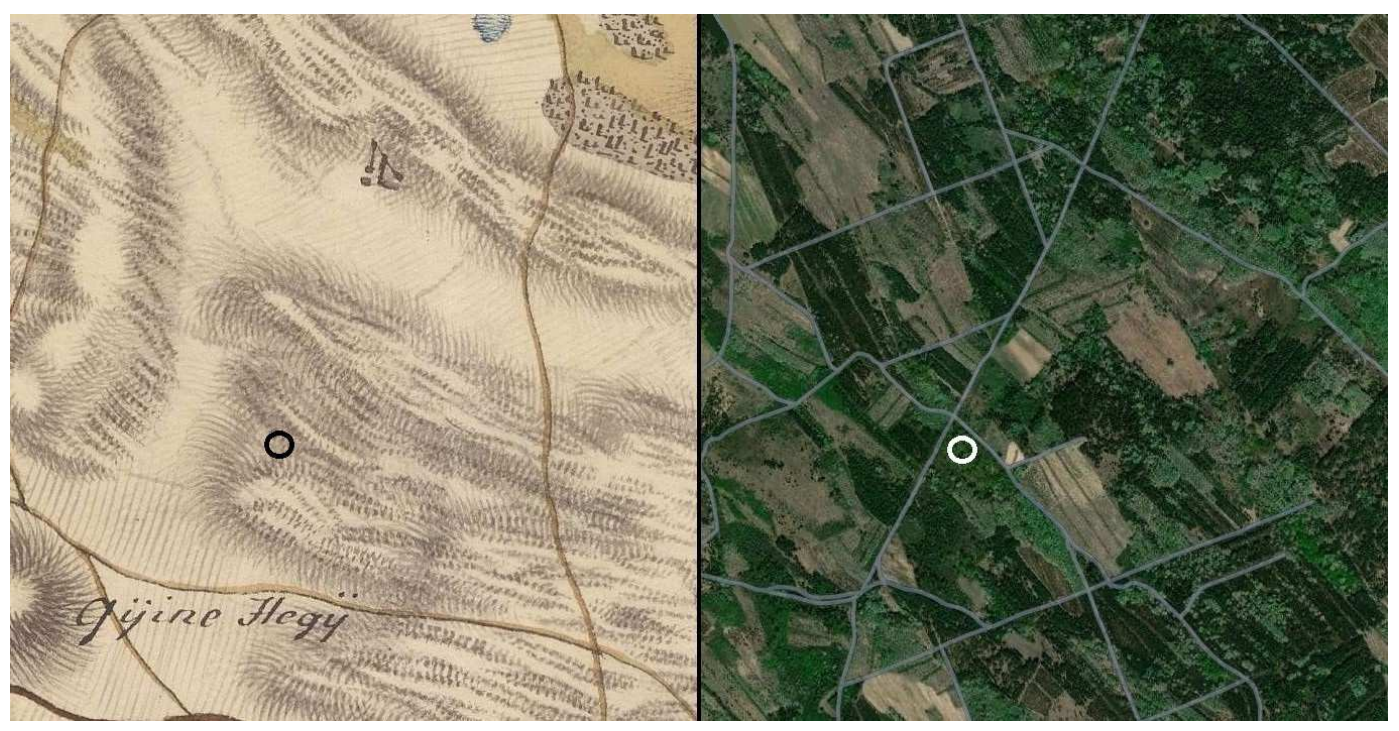

5. ábra A Müller-tölgyes és környéke az I. Katonai Felmérés idején és ma

Fig. 5 The 'Müller-tölgyes' (Kunadacs-Kunbaracs) on the First Military Survey maps of the Habsburg Empire (1763-1790) and on a present-day satellite map

Az őshonosság mellett érvelőket kissé elbizonytalaníthatják BABOS $(1954,1955,1958)$ tanulmányai, aki a Duna-Tisza köze gyöngyvirágos-tölgyeseinél (sőt egyes akácosoknál is!) javasolja az alsó lombkoronaszint kialakítását, amelyre a gyertyánt is alkalmasnak tartja. Nehéz lenne ezek után megállapítani, hogy BABos $(1954,1955,1958)$ javaslatát az elmúlt több mint 60-65 év alatt a Duna-Tisza közi erdészek mennyire vették figyelembe. Megemlítendő ezzel kapcsolatban a Kunadacs és Kunbaracs közötti ún. Müller-tölgyes (vö. GÁcSI 1961), amelyből három felvételt készítettem (17-19. sz. felvételek). Az erdészek telepítettnek tartják, ugyanis dokumentumok igazolják, hogy itt egy néhai Müller nevü erdész 1910 körül egy tölgyest telepített. A gyertyán esetleges telepítéséről azonban nincs dokumentum. Azt sem lehet tudni pontosan, hogy e tölgyek telepítése előtti időben mi boríthatta a területet? Az első katonai felmérés (1783-1984) térképén a Müller-tölgyes jelenlegi helyén valóban nincs erdő. A térkép szerint itt homoki legelők lehettek. E helytől északkeletre, nagyjából egy kilométerre Kunbaracs felé azonban kisebb-nagyobb erdőfoltok láthatók a térképen (5. 
ábra). Ezek szerint a mai Müller-tölgyes közelében volt egy refúgium terület, s feltehetően innen származhatnak a cönológiai felvételekben szereplő - a Duna-Tisza közén ritka - növények: Anemone ranunculodes, Carpinus betulus, Mercurialis perennis, Viola reichenbachiana. A második és harmadik katonai felmérés térképein a Müller-tölgyes helyén és közvetlen közelében már kisebb facsoportok, illetve cserjések láthatók. Kérdés, hogy spontán jöhettek létre? A Müller-tölgyes gyertyán állományának természetszerű előfordulását valószínűsíti, hogy a közelben van a kunbaracsi gyertyános-tölgyes (20-24. sz. felvételek), továbbá a Müllertölgyestől északnyugatra is van három gyertyán állomány. Ezek egyikéből cönológiai felvételt készítettem (16. sz. felv.), míg a másik két kicsiny állomány olyan fajszegénynek bizonyult, hogy kihagytam a felmérésből. Végül a Müller-tölgyes gyertyán állományának természetszerủ eredetére utal az is, hogy az itt készült cönológiai felvételek (17-19. sz. felvételek) faji összetétele igen hasonló a Duna-Tisza köze egyéb területein készült felvételekéhez, ezért mind a dendrogramon (3. ábra), mind pedig az ordinációs diagramokon (4. ábra) beleilleszkednek a többi felvétel közé.

\section{Köszönetnyilvánítás}

Köszönetem illeti azon botanikusokat, természetvédelmi őröket és erdészeket, akiktől hasznos információkat kaptam, illetve kitűnő terepismeretük révén segítségemre voltak a parányi gyertyános-tölgyes állományok felkeresésében: Csete Sándor, Csiky János, Hajdu Oszkár, Lendvai Gábor, Molnár Ábel, Molnár Zsolt, Nagy István, Rédei Tamás, Urbán Sándor, Vadász Csaba.

\section{Rövidítések}

A1: felső lombkoronaszint; A2: alsó lombkoronaszint; Adv: Adventiva; AF: Aremonio-fagion; Ai: Alnion incanae; Alo: Alopecurion pratensis; APa: Abieti-Piceea; AQ: Aceri tatarici-Quercion; Ara: Arrhenatheretalia; Arc: Arction lappae; Arn: Arrhenatherion elatioris; Ata: Alnetalia glutinosae; B1: cserjeszint; B2: újulat; Ber: Berberidion; Bia: Bidentetalia; C: gyepszint; Cau: Caucalidion platycarpos; CG: Calluno-Genistion; Cgr: Caricenion gracilis; Che: Chenopodietea; ChS: Chenopodio-Scleranthea; Cn: Calystegion sepium; Cp: Carpinenion betuli; Des: Deschampsion caespitosae; Epa: Epilobietalia; EPn: Erico-Pinion; EuF: Eu-Fagenion; F: Fagetalia sylvaticae; FB: Festuco-Bromea; FBt: Festuco-Brometea; FPe: Festuco-Puccinellietea; Fru: Festucion rupicolae; Fvg: Festucion vaginatae; Fvl: Festucetalia valesiacae; GA: Galio-Alliarion; I: Indifferens; ined.: ineditum (kiadatlan közlés); Mag: Magnocaricion; Moa: Molinietalia coeruleae; MoA: Molinio-Arrhenatherea; Moa: Molinio-Juncetea; NA: NardoAgrostion tenuis; OCn: Orno-Cotinion; Pla: Plantaginetalia majoris; Pna: Populenion nigro-albae; PQ: Pino-Quercion; Prf: Prunion fruticosae; Pru: Prunetalia spinosae; Pte: Phragmitetea; Qc: Quercetalia cerridis; Qfa: Quercion farnetto; QFt: Querco-Fagetea; Qpp: Quercetea pubescentis-petraeae; Qr: Quercetalia roboris; Qrp: Quercion robori-petraeae; S: summa (összeg); Sal: Salicion albae; SaS: SambucoSalicion capreae; Sea: Secalietea; s.l.: sensu lato (tágabb értelemben); Spu: Salicetalia purpureae; TA: Tilio platyphyllae-Acerenion pseudoplatani; Ulm: Ulmenion.

\section{Irodalom}

BABos I. (1954): Alsó koronaszintek létesítése a Duna-Tisza-köze homokhátán. - Erdőgazdaság 8(18): $10-11$.

BABos I. (1955): A Duna-Tisza közi homokhát termőhelyfeltárása. - Erdészeti Kutatások 2: 3-53.

BABos I. (1958): Szemelvények a homoki akácosok termőhelyvizsgálati eredményeiből. - Az MTA Agrártudományok Osztályának Közleményei 3-4: 381-398. 
Balczó A., Baranyai Zs., NAgy I., Sipos K. \& Schrett A. (2011): A Csévharaszti homokvidék kiemelt jelentőségú természetmegőrzési terület aktív kezelési zónájának fenntartási terve. - Duna-Ipoly Nemzeti Park Igazgatóság Természetmegőrzési Osztály, Budapest, 77 pp.

BECKING R. W. (1957): The Zürich-Montpellier School of phytosociology. - Botanical Review 23: 411-488.

BIRó M. (2008): A Duna-Tisza köze fásszárú vegetációjának átalakulása a 18. század óta, különös tekintettel a száraz homokterületekre. - In: KRöEl-Dulay Gy., KalAPos T. \& MojZES A. (szerk.), Talajvegetáció-klíma kölcsönhatások. Köszöntjük a 70 éves Láng Editet. MTA Ökológiai és Botanikai Kutatóintézete, Vácrátót, pp. 23-38.

BiRó M. \& MoLNÁR Zs. (2009): Az Alföld erdei a folyószabályozások és az alföldfásítás előtti évszázadban. - In: KÁzmér M. (szerk.), Környezettörténet. Az elmúlt 500 év környezeti eseményei történeti és természettudományi források tükrében. Hantken Kiadó, Budapest, pp. 167-206.

BoRHIDI A. (1961): Klimadiagramme und klimazonale Karte Ungarns - Annales Universitatis Scientiarum Budapestinensis, Sectio Biologica 4: 21-250.

Borhidi A. (1993): A magyar flóra szociális magatartás típusai, természetességi és relatív ökológiai értékszámai. - Janus Pannonius Tudományegyetem, Pécs, 95 pp.

BoRHIDI A. (1995): Social behaviour types, the naturalness and relative ecological indicator values of the higher plants in the hungarian flora. - Acta Botanica Academiae Scientiarum Hungaricae 39: 97181.

Borhidi A. \& Kevey B. (1996): An annotated checklist of the Hungarian plant communities II. - In: Borhidi A. (ed.), Critical revision of the Hungarian plant communities. Janus Pannonius University, Pécs, pp. 95-138.

Borhidi A., Kevey B. \& Lendvai G. (2012): Plant communities of Hungary. - Akadémiai Kiadó, Budapest, $544 \mathrm{pp}$.

BoRos Á. (1935a): A nagykőrösi homoki erdők növényvilága. - Erdészeti Kísérletek 37: 1-24.

Boros Á. (1935b): A nagykőrös vidéki homoki erdők növényvilága. - Nagykőrösi Múzeumkör Kiadványai, $22 \mathrm{pp}$.

BRAUn-BlanqueT J. (1964): Pflanzensoziologie. - Ed. 3. Springer Verlag, Wien-New York, 865 pp.

Bund K. (1921): A gyertyán térfoglalásának kérdéséhez. - Erdészeti Lapok 60(19-20): 341-346.

CsÁKY P. (2018): A Turjánvidék északi részének florisztikai szempontból jelentős növényfajai. - In: KoRda M. (szerk.), Természetvédelem és kutatás a Turjánvidék északi részén. Duna-Ipoly Nemzeti Park Igazgatóság, Budapest, pp. 145-252.

FRIVALDSZKY I. (1859): Hazánk faunájára vonatkozó adatok és a Puszta-peszéri erdő. - A Magyar Tudós Társaság Évkönyvei 9: 19-28.

GÁCSI J. (1961): Madártelepítési tapasztalatok középkorú alföldi tölgyesekben. - Erdészeti Lapok 1963 (11): 511-518.

HorvÁth F., Dobolyi Z. K., MorschHAUSER T., LőKÖS L., KARAS L. \& SZERDAhElYI T. (1995): Flóra adatbázis 1.2. - Vácrátót, 267 pp.

ISSLER E. (1931): Les associations silvatiques haut-rhinoises. - Bulletin de la Société Botanique de France 78: $62-141$.

JAKUCS P. (1967): Gedanken zur höheren Systematik der europäischen Laubwälder. - Contribuţii Botanice Cluj 1967: 159-166.

KERNER A. (1876): Die Vegetations-Verhältnisse des mittleren und östlichen Ungarns und angrenzenden Siebenbürgens 86. - Österreichische Botanische Zeitschrift 26: 259-261.

KEvEy B. (2008): Magyarország erdőtársulásai (Forest associations of Hungary). Die Wälder von Ungarn - Tilia 14: 1-488. + CD-adatbázis (230 táblázat + 244 ábra).

Kevey B. (2014): A Bakonyalja homokvidékének erdei V.: Gyertyános-tölgyesek (Convallario-Carpinetum [KeVeY 1998]). - Folia Musei Historico-naturalis Bakonyiensis 31: 47-72.

KEVEY B. \& Hirmann A. (2002): „NS” számítógépes cönológiai programcsomag. - In: Aktuális flóra- és vegetációkutatások a Kárpát-medencében V. Pécs, 2002. március 8-10. (Összefoglalók), p. 74.

Kevey B. \& LendVAi G. (2015): A Tengelici-homokvidék gyertyános-tölgyesei (Convallario-Carpinetum KEVEY 2008). - Natura Somogyiensis 26: 5-37.

Kevey B., PAPP L. \& LendVAi G. (2017): A Nyírség gyertyános-tölgyesei (Convallario-Carpinetum KeveY 2008). - Botanikai Közlemények 104(1): 147-164 + Elektronikus mellékletek: E1-E3 táblázat.

LUQUET A. (1926): Essai sur la geographie botanique de l'Auvergne. Les associations végétales du Massif des Monts-Dores. - Geographie Botanique de l'Auvergne. Les Presses Universitaires de France, Paris, pp. 1-263. 
Mucina L., GRABHERR G. \& WALLnÖFER, S. (1993): Die Pflanzengesellschaften Österreichs III. Wälder und Gebüsche. - Gustav Fischer, Jena - Stuttgart - New York, 353 pp.

OBERDORFER E. (1992): Süddeutsche Pflanzengesellschaften IV. A. Textband. - Gustav Fischer Verlag, Jena - Stuttgart - New York, 282 pp.

PAWŁowski B., SокоŁowski M. \& WALlisch K. (1928): Die Pflanzenassoziationen des Tatra-Gebirges VII. Die Pflanzenassoziationen und die Flora des Morskie Oko-Tales. - Bulletin International de l'Academie Polonaise des Sciences et des Lettres, Classe des Sciences Mathématiques et Naturelles; Série B: Sciences Naturelles, Cracovie, Suppl. 1927: 205-272.

PoDANI J. (2001): SYN-TAX 2000 Computer Programs for Data Analysis in Ecologi and Systematics. Scientia, Budapest, $53 \mathrm{pp}$.

Soó R. (1964, 1966, 1968, 1970, 1973, 1980): A magyar flóra és vegetáció rendszertani-növényföldrajzi kézikönyve I-VI. - Akadémiai Kiadó, Budapest.

Tóтн K. (1973): Természetvédelem Bács-Kiskun megyében. - Erdészeti Lapok 108(5): 227-232.

VLIEGER J. (1937): Aperçu sur les unités phytosociologiques supérieures des Pays-Bas. - Nederlandsh Kruidkundig Archief 47: 335.

Beérkezett / received: 2020. 06. 09. • Elfogadva / accepted: 2020. 10.13.

1. táblázat Convallario-Quercetum roboris

Table 1 Convallario-Quercetum roboris

\begin{tabular}{|c|c|c|c|c|c|c|c|c|c|c|c|c|c|c|c|c|c|c|c|c|c|c|c|c|c|c|c|c|c|}
\hline & Szint & 1 & 23 & 34 & 45 & & & 78 & 8 & 9 & & $\begin{array}{ll}12 \\
12\end{array}$ & & 1 & & 5 & $\begin{array}{l}1 \\
6 \\
\end{array}$ & $\begin{array}{l}1 \\
7 \\
\end{array}$ & 8 & 9 & $\mathbf{0}$ & 1 & & 3 & & 5 & A-D & $\mathbf{K}$ & $\mathbf{K} \%$ \\
\hline \multicolumn{30}{|l|}{$\begin{array}{l}\text { 1. Querco-Fagea } \\
\text { 1.1. Salicetea purpureae } \\
\text { 1.1.1. Salicetalia purpureae }\end{array}$} \\
\hline $\begin{array}{l}\text { Populus nigra } \\
\text { 1.1.1.1. Salicion albae }\end{array}$ & $\mathrm{A} 1$ & - & - - & $-\quad-$ & -+ & +- & - & - & - & - & - & & & - & - & - & - & - & - & - & - & - & - & - & - & & + & I & 4 \\
\hline Cucubalus baccifer (Cn, Ulm) & $\mathrm{C}$ & + & ++ & +- & -+ & + & + & ++ & ++ & + & -+ & + & + & + & - & + & - & - & - & - & + & + & + & + & + & + & + & IV & 68 \\
\hline \multirow[t]{4}{*}{ Humulus lupulus (Cn, Ata, Ai) } & B1 & + & - + & +- & $-\quad+$ & +- & - & - & - & - & - & - & - & + & - & + & - & - & - & - & - & - & - & - & - & & + & I & 20 \\
\hline & B2 & - & $-\quad+$ & +- & $-\quad-$ & - & - - & - & - & 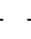 & $-\quad-$ & - & - & - & - & - & - & - & - & - & - & - & - & - & - & & + & I & 4 \\
\hline & C & + & $-\quad-$ & $-\quad-$ & $-\quad+$ & +- & + & + & + & - & $-\quad-$ & & + & + & - & + & + & - & + & + & + & + & + & - & + & & + & III & 56 \\
\hline & S & + & $-\quad+$ & + & $-\quad+$ & + & + & + & + & - & $-\quad-$ & & + & + & - & + & + & - & + & + & + & + & + & - & + & & + & III & 60 \\
\hline \multicolumn{30}{|l|}{ 1.2. Querco-Fagetea } \\
\hline \multirow[t]{4}{*}{ Crataegus monogyna (Qpp) } & $\mathrm{A} 2$ & - & $-\quad-$ & $-\quad-$ & - 1 & 1 - & - - & - & - & 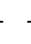 & - & - & - & - & - & - & - & - & - & - & - & + & - & - & + & - & +-1 & I & 12 \\
\hline & B1 & 1 & ++ & +3 & 32 & $2-$ & + & +1 & 11 & 1. & ++ & +1 & 1 & 1 & 1 & 1 & 2 & 1 & 1 & 2 & 2 & 1 & 1 & 2 & - & + & +-3 & $\mathrm{~V}$ & 92 \\
\hline & B2 & + & ++ & ++ & ++ & ++ & ++ & + & + & & + & + & + & - & + & + & + & + & + & + & + & + & + & + & + & + & + & $\mathrm{V}$ & 92 \\
\hline & S & 1 & ++ & +3 & 32 & $2+$ & ++ & +1 & 11 & 1. & ++ & +1 & 1 & 1 & 1 & 1 & 2 & 1 & 1 & 2 & 2 & 1 & 1 & 2 & + & + & +-3 & $\mathrm{~V}$ & 100 \\
\hline \multirow[t]{3}{*}{ Euonymus europaeus (Qpp) } & B1 & 1 & ++ & +- & - & - & + & + & + & + & - & - & - & - & - & - & - & - & + & + & - & + & - & - & + & - & +-1 & II & 36 \\
\hline & B2 & + & ++ & ++ & ++ & ++ & ++ & + & ++ & + & ++ & + & + & + & + & + & + & + & + & - & + & + & + & + & + & + & + & $\mathrm{V}$ & 96 \\
\hline & $S$ & 1 & ++ & ++ & ++ & ++ & ++ & + & + & + & + & + & + & + & + & + & + & + & + & + & + & + & + & + & + & + & +-1 & $\mathrm{~V}$ & 100 \\
\hline \multirow[t]{3}{*}{ Ligustrum vulgare (Cp, Qpp) } & B1 & +2 & 22 & 21 & 13 & $3+$ & +1 & $1+$ & +1 & 1 & 22 & 22 & 2 & 1 & 1 & 1 & 2 & 1 & 2 & 2 & 2 & + & 1 & 1 & 1 & - & +-3 & $\mathrm{~V}$ & 96 \\
\hline & B2 & + & 12 & 21 & 12 & $2+$ & +1 & $1-$ & 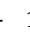 & 1 & +1 & 1 & 1 & + & 1 & + & 1 & 1 & 1 & 2 & 1 & + & + & + & 1 & + & +-2 & $\mathrm{~V}$ & 96 \\
\hline & S & +2 & 23 & 32 & 24 & $4+$ & +2 & $2+$ & +2 & 2 & 22 & 22 & 2 & 1 & 2 & 1 & 2 & 2 & 2 & 3 & 2 & + & 1 & 1 & 2 & + & +-4 & $\mathrm{~V}$ & 100 \\
\hline \multirow[t]{5}{*}{ Quercus robur (Ai, Cp, Qpp) } & $\mathrm{A} 1$ & 4 & 44 & 44 & 43 & 33 & 34 & 44 & 4 & 4 & 45 & 5 & 4 & 4 & 4 & 3 & 3 & 4 & 4 & 4 & 5 & 4 & 4 & 3 & 4 & 3 & $3-5$ & $\mathrm{~V}$ & 100 \\
\hline & A2 & - & $-\quad-$ & -1 & 1 - & 1 & $1-$ & + & +1 & 1 & 1 . & - & - & - & + & 1 & - & - & - & - & + & - & - & - & - & - & +-1 & II & 32 \\
\hline & B1 & - & $-\quad-$ & $-\quad-$ & $-\quad-$ & - & - - & - & - & - & $-\quad-$ & - & - & - & - & - & - & - & - & - & - & + & - & - & - & - & + & I & 4 \\
\hline & B2 & + & ++ & ++ & ++ & ++ & ++ & + & + & + & + & & + & + & + & + & + & + & + & + & + & + & + & - & + & + & + & $\mathrm{V}$ & 92 \\
\hline & $S$ & 4 & 44 & 44 & 43 & 33 & 34 & 44 & 4 & 4 & 4 & 5 & 4 & 4 & 4 & 3 & 3 & 4 & 4 & 4 & 5 & 4 & 4 & 3 & 4 & 3 & $3-5$ & $\mathrm{~V}$ & 100 \\
\hline Brachypodium sylvaticum (Qpp) & $\mathrm{C}$ & + & ++ & +1 & $1-$ & 2 & 2 & + & + & + & + & + & + & + & + & + & + & + & 1 & 1 & 1 & + & + & 1 & + & + & +-2 & $\mathrm{~V}$ & 96 \\
\hline Polygonatum latifolium (Qpp) & $\mathrm{C}$ & 22 & 22 & 22 & $2+$ & +2 & 22 & 22 & 22 & 2 & 23 & 3 & 2 & 3 & 2 & 3 & 2 & - & + & + & 1 & 1 & 1 & + & 1 & 1 & +-3 & $\mathrm{~V}$ & 96 \\
\hline \multirow[t]{4}{*}{ Cornus sanguinea (Qpp) } & $\mathrm{A} 2$ & - & $-\quad-$ & $-\quad-$ & $-\quad-$ & - - & - & - & 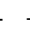 & + & - & - & - & - & - & - & - & - & - & - & - & - & - & - & - & - & + & I & 4 \\
\hline & B1 & - & ++ & +- & -+ & +2 & 21 & 11 & 12 & 2 & + & & 1 & 1 & 1 & 1 & + & - & + & - & 1 & 1 & + & 1 & 1 & & +-2 & IV & 76 \\
\hline & B2 & - & $-\quad-$ & $-\quad+$ & ++ & +1 & 1 & + & & + & & & + & + & & - & - & - & + & - & 1 & + & + & + & + & & +-1 & III & 60 \\
\hline & $\mathrm{S}$ & & ++ & ++ & ++ & +2 & & 11 & & 2 & & & 1 & 1 & 1 & 1 & + & - & + & - & 2 & & + & 1 & 1 & & +-2 & $\mathrm{~V}$ & 84 \\
\hline
\end{tabular}


Kitaibelia 26(1): 49-76.

\begin{tabular}{|c|c|c|c|c|c|c|c|c|c|c|c|c|c|c|c|c|c|c|c|c|c|c|c|c|c|c|c|c|c|}
\hline & Szint & 1 & 23 & & 4 & 5 & 6 & 7 & 8 & 9 & $\begin{array}{l}\mathbf{1} \\
\mathbf{0}\end{array}$ & $\mathbf{1}$ & $\begin{array}{l}1 \\
2 \\
\end{array}$ & $\begin{array}{l}1 \\
3 \\
\end{array}$ & $\begin{array}{l}1 \\
4 \\
\end{array}$ & $\begin{array}{l}1 \\
5 \\
\end{array}$ & $\begin{array}{l}1 \\
6 \\
\end{array}$ & $\begin{array}{l}1 \\
7 \\
\end{array}$ & $\begin{array}{l}1 \\
8\end{array}$ & 9 & & 1 & & & & $\begin{array}{r}2 \\
5 \\
\end{array}$ & A-D & $\mathbf{K}$ & $\mathbf{K} \%$ \\
\hline Dactylis polygama (Qpp, Cp) & $\mathrm{C}$ & + & +1 & 1 & + & - & + & + & + & + & + & + & - & + & - & + & + & + & + & + & + & + & + & + & & - & +-1 & $\mathrm{~V}$ & 84 \\
\hline Geum urbanum (Еpa, Cp, Qpp) & $\mathrm{C}$ & + & ++ & + & + & + & - & + & + & + & + & + & + & + & + & + & + & - & - & - & + & + & + & + & & + & + & $\mathrm{V}$ & 84 \\
\hline \multirow[t]{4}{*}{ Rhamnus catharticus (Qpp, Pru) } & A2 & - & $-\quad-$ & - & - & + & - & - & - & - & - & - & - & - & - & - & - & - & - & - & - & - & - & - & - & - & + & I & 4 \\
\hline & B1 & - & - - & & 2 & 1 & - & + & + & - & - & - & - & - & + & + & + & 2 & 2 & 2 & - & - & - & - & & - & +-2 & II & 40 \\
\hline & B2 & - & - - & & + & + & + & + & + & + & + & + & + & - & + & + & - & + & + & + & + & + & + & - & & + & + & IV & 72 \\
\hline & S & - & - - & -2 & 2 & 1 & + & + & + & + & + & + & + & - & + & + & + & 2 & 2 & 2 & + & + & + & - & & + & +-2 & IV & 76 \\
\hline Convallaria majalis (Qpp) & $\mathrm{C}$ & 2 & ++ & + & - & - & - & 1 & 2 & 2 & 2 & 2 & 2 & 1 & 2 & 1 & + & - & - & - & 2 & 1 & 1 & + & 1 & $1-$ & +-2 & IV & 72 \\
\hline Veronica sublobata & $\mathrm{C}$ & + & 21 & 1 & + & 1 & - & + & - & + & + & + & + & + & + & + & - & - & - & - & 1 & + & - & + & + & +2 & +-2 & IV & 72 \\
\hline Fallopia dumetorum (Qpp, GA) & $\mathrm{C}$ & + & +- & - & + & + & - & - & - & + & - & + & + & + & - & - & + & - & + & + & + & + & + & - & + & + & + & IV & 64 \\
\hline Geranium robertianum (Epa) & $\mathrm{C}$ & + & ++ & + & + & - & - & - & - & - & + & + & + & + & + & + & - & - & - & - & + & + & + & + & + & + & + & IV & 64 \\
\hline \multirow[t]{4}{*}{ Ulmus minor (Ai, Ulm, Qpp) } & A2 & + & +- & - & - & + & - & 1 & + & - & - & + & + & - & - & + & - & - & - & - & - & - & - & - & - & - & +-1 & II & 32 \\
\hline & B1 & + & - - & - & - & + & - & + & + & - & + & + & + & 1 & + & + & + & - & - & - & - & - & - & - & - & - & +-1 & III & 44 \\
\hline & B2 & + & +- & - & + & + & + & + & + & - & + & + & - & + & + & + & - & - & - & - & - & - & - & - & - & + & + & III & 52 \\
\hline & $S$ & 1 & +- & - & + & 1 & + & 1 & 1 & - & + & 1 & + & 1 & + & 1 & + & - & - & - & - & - & - & - & - & + & +-1 & III & 60 \\
\hline Viola suavis s.l. (Qpp) & $\mathrm{C}$ & + & 11 & 1 & 2 & 2 & - & - & - & + & 1 & + & - & - & + & - & + & - & + & + & + & - & + & - & - & 2 & +-2 & III & 60 \\
\hline \multicolumn{30}{|l|}{ Lapsana communis (Qpp, GA, } \\
\hline Ера) & $\mathrm{C}$ & - & ++ & + & + & - & + & + & + & - & + & + & - & + & + & + & - & - & - & - & - & + & - & + & & + & + & III & 56 \\
\hline Ranunculus ficaria & $\mathrm{C}$ & - & 11 & 1 & - & - & + & + & 2 & 2 & + & 1 & 1 & 2 & 1 & 1 & - & - & - & - & - & - & - & - & - & - & +-2 & III & 48 \\
\hline Ajuga reptans $(\mathrm{MoA})$ & $\mathrm{C}$ & - & $-\quad-$ & - & - & - & + & + & + & + & + & + & + & + & + & 1 & - & 1 & - & - & - & - & - & - & - & - & +-1 & III & 44 \\
\hline Bromus ramosus agg. (Qpp) & $\mathrm{C}$ & - & - & - & - & - & + & + & + & + & + & + & + & + & + & + & - & - & - & - & - & - & - & + & - & - & + & III & 44 \\
\hline Scrophularia nodosa (GA, Epa) & $\mathrm{C}$ & - & -+ & + & - & - & - & - & + & - & + & + & + & + & - & - & - & - & - & - & + & + & + & ++ & + & + & + & III & 44 \\
\hline $\begin{array}{l}\text { Campanula trachelium (Epa, Cp) } \\
\text { Heracleum sphondylium (Qpp, }\end{array}$ & $\mathrm{C}$ & - & $-\quad-$ & - & - & - & + & + & + & + & + & + & + & + & + & - & - & - & - & - & - & - & - & - & - & - & + & II & 36 \\
\hline MoA) & $\mathrm{C}$ & + & - & - & - & - & - & - & + & + & + & + & + & + & + & + & - & - & - & - & - & - & - & - & - & - & + & II & 36 \\
\hline Mycelis muralis & C & - & - & - & - & - & - & + & + & + & - & - & - & + & - & - & + & - & + & + & - & - & - & - & - & + & + & II & 32 \\
\hline Poa nemoralis (Qpp) & $\mathrm{C}$ & + & +1 & 1 & + & - & - & - & - & - & - & + & + & - & - & + & - & + & - & - & - & - & - & - & - & - & +-1 & II & 32 \\
\hline \multirow[t]{4}{*}{ Corylus avellana (Qpp) } & $\mathrm{A} 2$ & - & - & - & - & - & - & - & - & - & - & - & - & - & - & - & - & - & - & - & - & - & - & - & & - & 2 & I & 4 \\
\hline & B1 & - & +1 & 1 & - & - & - & - & - & - & - & - & - & - & - & - & - & - & - & - & 1 & 1 & 1 & 12 & & $2-$ & +-2 & II & 28 \\
\hline & B2 & - & $-\quad-$ & - & - & - & - & - & - & - & - & - & - & - & - & - & - & - & - & - & - & + & + & ++ & & - & + & I & 16 \\
\hline & S & - & +1 & 1 & - & - & - & - & - & - & - & - & - & - & - & - & - & - & - & - & 1 & 1 & 1 & 12 & 3 & $3-$ & +-3 & II & 28 \\
\hline \multirow[t]{3}{*}{ Clematis vitalba (Qpp) } & B1 & - & - & - & - & - & - & - & + & + & - & - & - & - & - & - & - & - & - & - & - & - & - & - & - & - & + & I & 8 \\
\hline & B2 & - & $-\quad$ & - & - & - & + & + & + & + & - & + & - & - & - & - & - & - & - & - & - & - & - & - & - & - & + & I & 20 \\
\hline & $S$ & - & $-\quad-$ & - & - & - & + & + & + & + & - & + & - & - & - & - & - & - & - & - & - & - & - & - & - & - & + & I & 20 \\
\hline \multirow[t]{4}{*}{ Acer campestre (Qpp) } & $\mathrm{A} 2$ & 1 & +1 & 1 & - & - & - & - & - & - & - & - & - & - & - & - & - & 1 & - & - & - & - & - & - & - & - & +-1 & I & 16 \\
\hline & B1 & 1 & -+ & + & - & - & - & - & - & - & - & - & - & - & - & - & - & + & - & - & - & - & - & - & - & - & +-1 & I & 12 \\
\hline & B2 & + & ++ & + & - & - & - & - & - & - & - & - & - & - & - & - & - & + & - & - & - & - & - & - & - & - & + & I & 16 \\
\hline & S & 2 & +1 & 1 & - & - & - & - & - & - & - & - & - & - & - & - & - & 1 & - & - & - & - & - & - & - & - & +-2 & I & 16 \\
\hline \multirow[t]{4}{*}{ Populus tremula (Qr, Qc, Ber) } & A2 & - & - - & - & - & - & - & - & + & - & - & - & - & - & - & - & - & - & - & - & - & - & - & - & - & - & + & I & 4 \\
\hline & B1 & - & $-\quad-$ & - & - & - & - & - & - & - & - & - & - & - & - & - & - & - & - & - & - & + & - & - & - & - & + & I & 4 \\
\hline & B2 & - & - - & - & - & - & - & - & + & - & - & - & - & - & - & - & - & - & - & - & - & - & + & +- & & + & + & I & 12 \\
\hline & S & - & - - & - & - & - & - & - & + & - & - & - & - & - & - & - & - & - & - & - & - & + & + & +- & & + & + & I & 16 \\
\hline \multicolumn{30}{|l|}{ Cephalanthera damasonium } \\
\hline Galeopsis pubescens (Qpp, Еpa) & $\mathrm{C}$ & - & - & - & - & - & - & - & - & - & - & - & - & - & - & - & - & - & - & - & - & + & - & + & & - & + & I & 12 \\
\hline Symphytum tuberosum (Cp, Qpp) & $\mathrm{C}$ & - & - & - & - & - & - & - & - & - & - & - & - & - & - & - & - & - & - & - & + & - & + & ++ & - & - & + & I & 12 \\
\hline Carex divulsa & $\mathrm{C}$ & + & - & - & - & - & - & - & - & - & - & - & - & - & - & - & - & - & - & - & - & - & - & - & - & + & + & I & 8 \\
\hline \multicolumn{30}{|l|}{ 1.2.1. Fagetalia sylvaticae } \\
\hline Carpinus betulus (Cp) & $\mathrm{A} 1$ & 2 & 11 & 1 & 1 & 3 & 1 & 2 & 2 & - & 2 & 1 & - & 1 & 1 & 1 & - & - & - & - & - & 1 & & 13 & $5-$ & 3 & $1-3$ & IV & 68 \\
\hline & A2 & 2 & 33 & 3 & 2 & 2 & 2 & 2 & 2 & 2 & 2 & 2 & 2 & 2 & 3 & 2 & 4 & 3 & 3 & 3 & 3 & 3 & & 33 & 2 & 3 & $2-4$ & $\mathrm{~V}$ & 100 \\
\hline & B1 & + & -+ & & + & + & 2 & 2 & + & - & 1 & 1 & 2 & 1 & + & 1 & 2 & 1 & 1 & + & - & 2 & 2 & 21 & 2 & 1 & +-2 & $\mathrm{~V}$ & 88 \\
\hline & B2 & - & ++ & + & - & + & + & + & + & + & + & - & + & + & + & + & + & + & - & + & + & + & + & ++ & + & + & + & $\mathrm{V}$ & 84 \\
\hline & S & 3 & 33 & 3 & 2 & 4 & 3 & 3 & 3 & 2 & 3 & 2 & 3 & 2 & 3 & 2 & 5 & 3 & 3 & 3 & 3 & 4 & 4 & 45 & 3 & 5 & $2-5$ & $\mathrm{~V}$ & 100 \\
\hline
\end{tabular}


KEVEY (2021): A Duna-Tisza köze gyertyános-tölgyesei

\begin{tabular}{|c|c|c|c|c|c|c|c|c|c|c|c|c|c|c|c|c|c|c|c|c|c|c|c|c|c|c|c|c|c|c|}
\hline & Szint & 1 & 2 & 3 & 4 & 5 & 6 & 7 & 8 & 9 & & $\begin{array}{l}1 \\
1\end{array}$ & $\begin{array}{l}1 \\
2 \\
\end{array}$ & $\begin{array}{r}11 \\
23 \\
\end{array}$ & & & & & & & & $\begin{array}{l}2 \\
0 \\
\end{array}$ & $\begin{array}{l}2 \\
1 \\
\end{array}$ & $\begin{array}{l}2 \\
2 \\
\end{array}$ & $\begin{array}{l}2 \\
3 \\
\end{array}$ & & $\begin{array}{l}2 \\
5 \\
\end{array}$ & A-D & $\mathbf{K}$ & $\mathbf{K} \%$ \\
\hline Moehringia trinervia & $\mathrm{C}$ & - & - & - & + & 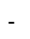 & - & - & - & + & + & + & + & +- & + & + & + & - & - & - & - & + & + & + & + & + & - & + & III & 48 \\
\hline Paris quadrifolia (Ata, Ai) & $\mathrm{C}$ & - & - & - & - & - & + & + & + & + & + & + & + & +1 & $1+$ & + & + & - & - & - & - & - & - & - & - & - & - & +-1 & II & 40 \\
\hline Viola reichenbachiana & $\mathrm{C}$ & - & - & - & - & + & - & - & - & - & - & - & - & - & - & - & + & +1 & $1+$ & ++ & + & + & + & + & + & + & - & +-1 & II & 40 \\
\hline Epipactis helleborine agg. & $\mathrm{C}$ & - & - & - & - & - & + & + & + & + & - & - & - & + & ++ & + & +- & - & - & - & - & - & - & - & - & - & + & + & II & 32 \\
\hline Polygonatum multiflorum (QFt) & $\mathrm{C}$ & - & - & - & - & - & + & + & + & + & 1 & - & - & + & ++ & - & - & - & - & - - & - & - & - & - & - & - & - & +-1 & II & 28 \\
\hline \multirow[t]{4}{*}{ Acer pseudo-platanus (TA) } & A2 & - & - & - & - & - & - & - & - & - & - & - & + & +- & - & - & - & - & - & - & - & - & - & - & - & - & - & + & I & 4 \\
\hline & B1 & - & - & - & - & - & - & - & - & - & - & - & + & + & - - & - & - & -+ & + & $-\quad-$ & - & - & - & - & - & - & - & + & I & 8 \\
\hline & B2 & - & - & - & - & + & - & - & - & - & - & + & - & + & +- & - & - & -+ & + & $-\quad-$ & - & - & - & - & - & - & - & + & I & 16 \\
\hline & S & - & - & - & - & + & - & - & - & - & - & + & + & ++ & +- & - & - & -+ & + & $-\quad-$ & - & - & - & - & - & - & - & + & I & 20 \\
\hline \multirow[t]{3}{*}{ Acer platanoides (TA) } & B1 & - & - & - & - & - & - & - & - & - & - & + & - & - & - & - & - & - & - & $-\quad-$ & - & - & - & - & - & 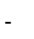 & 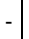 & + & I & 4 \\
\hline & B2 & + & - & - & - & - & - & - & + & - & - & - & + & +- & - & - & - & - & $-\quad-$ & $-\quad-$ & - & - & - & - & - & - & - & + & I & 12 \\
\hline & $S$ & + & - & - & - & - & - & - & + & - & - & + & + & +- & - - & - & - & $-\quad-$ & $-\quad-$ & $-\quad-$ & - & - & - & - & - & - & - & + & I & 16 \\
\hline Circaea lutetiana (Ai) & $\mathrm{C}$ & - & - & - & - & - & - & - & + & 1 & - & - & - & + & +- & - & - - & - & - & - & - & - & - & - & - & - & 1 & +-1 & I & 16 \\
\hline \multirow[t]{3}{*}{ Hedera helix } & $\mathrm{A} 2$ & 2 & - & - & - & - & - & - & - & - & - & - & - & - & - & - & - - & - & - & - - & - & - & - & - & - & - & - & 2 & I & 4 \\
\hline & B2 & 4 & - & - & - & - & - & - & - & - & - & - & - & - & - & - & + & +- & - & - & - & - & + & - & - & + & - & +-4 & I & 16 \\
\hline & $S$ & 5 & - & - & - & - & - & - & - & - & - & - & - & - & - & - & + & +- & - & - & - & - & + & - & - & + & - & +-5 & I & 16 \\
\hline Anemone ranunculoides & $\mathrm{C}$ & - & - & - & - & - & - & - & + & - & - & - & - & + & +- & - & - - & -+ & +- & & - & - & - & - & - & - & - & + & I & 12 \\
\hline \multirow{3}{*}{ Cerasus avium (Cp) } & $\mathrm{A} 1$ & 1 & - & - & - & - & - & - & - & - & - & - & - & - & - & - & - & - & - & & - & - & - & - & - & - & - & 1 & I & 4 \\
\hline & B2 & + & - & - & - & - & + & - & - & - & - & - & - & + & +- & - & - - & $-\quad-$ & $-\quad-$ & & - & - & - & - & - & - & - & + & I & 12 \\
\hline & S & 1 & - & - & - & - & + & - & - & - & - & - & - & + & +- & - & - - & - & - & $-\quad-$ & & - & - & - & - & - & - & +-1 & I & 12 \\
\hline Viola riviniana (Qr, $\mathrm{PQ})$ & $\mathrm{C}$ & - & - & - & - & - & - & - & - & - & - & - & - & - & - & - & - - & - & - & - - & - & + & - & + & + & - & - & + & I & 12 \\
\hline Arum orientale & $\mathrm{C}$ & - & + & 1 & - & - & - & - & - & - & - & - & - & - & - & - & - & - & - & - - & - & - & - & - & - & - & - & +-1 & I & 8 \\
\hline Listera ovata (Ata, Ai) & $\mathrm{C}$ & - & - & - & - & - & 1 & + & - & - & - & - & - & - - & - & - & - - & - & - & & - & - & - & - & - & - & - & +-1 & I & 8 \\
\hline Carex sylvatica & $\mathrm{C}$ & - & - & + & - & - & - & - & - & - & - & - & - & - - & - & - & - - & - & - - & - - & - & - & - & - & - & - & - & + & I & 4 \\
\hline Corydalis cava & $\mathrm{C}$ & - & - & - & - & - & - & - & - & + & - & - & - & - & - & - & - - & - & - & - & - & - & - & - & - & - & - & + & I & 4 \\
\hline Epipactis microphylla & $\mathrm{C}$ & - & - & - & - & - & + & - & - & - & - & - & - & - & - & - & - & - & - & - & - & - & - & - & - & - & - & + & I & 4 \\
\hline Fagus sylvatica (EuF) & $\mathrm{A} 1$ & 1 & - & - & - & - & - & - & - & - & - & - & - & - & - - & - & - & - & - & - & - & - & - & - & - & - & - & 1 & I & 4 \\
\hline Galeobdolon luteum & $\mathrm{C}$ & + & - & - & - & - & - & - & - & - & - & - & - & - & - - & - & - - & - & - & - & - & - & - & - & - & - & - & + & I & 4 \\
\hline Mercurialis perennis & $\mathrm{C}$ & - & - & - & - & - & - & - & - & - & - & - & - & - & - & - & - & -2 & 2 & - & - & - & - & - & - & - & - & 2 & I & 4 \\
\hline \multirow[t]{4}{*}{ Ulmus glabra (TA) } & A2 & - & - & - & - & - & - & - & - & - & - & - & - & - & - & - & & +- & - & - & - & - & - & - & - & - & - & + & I & 4 \\
\hline & B1 & - & - & - & - & - & - & - & - & - & - & - & - & - & - & - & & 1 - & - & - & - & - & - & - & - & - & - & 1 & I & 4 \\
\hline & B2 & - & - & - & - & - & - & - & - & - & - & - & - & - & - & - & & + & - & - & - & - & - & - & - & - & - & + & I & 4 \\
\hline & $S$ & - & - & - & - & - & - & - & - & - & - & - & - & - & - & - & & 1 - & - & - & - & - & - & - & - & - & - & 1 & I & 4 \\
\hline \multirow{6}{*}{$\begin{array}{l}\text { 1.2.1.1. Alnion incanae } \\
\text { Fraxinus angustifolia ssp. } \\
\text { danubialis (Ata) }\end{array}$} & & & & & & & & & & & & & & & & & & & & & & & & & & & & & & \\
\hline & $\mathrm{A} 1$ & - & - & - & - & - & 3 & 1 & 2 & 1 & 1 & 1 & 2 & 21 & 12 & 3 & $3-$ & - & - & - & - & - & - & - & - & - & - & $1-3$ & II & 40 \\
\hline & $\mathrm{A} 2$ & - & - & - & - & - & 1 & + & 1 & 1 & 1 & 1 & - & 2 & 21 & $1-$ & - & - & -1 & 1 & 1 & 1 & + & + & 1 & - & - & +-2 & III & 56 \\
\hline & B1 & - & - & - & + & - & - & 2 & 2 & 2 & 2 & 2 & 2 & 23 & 33 & 2 & 2 & + & + & - & - & + & - & + & + & - & - & +-3 & III & 56 \\
\hline & B2 & - & - & - & + & - & 1 & 1 & 2 & 1 & 1 & + & 1 & 12 & 22 & 2 & $2+$ & + & + & + & + & + & + & - & + & + & + & +-2 & IV & 80 \\
\hline & $S$ & - & - & - & + & - & 3 & 2 & 3 & 2 & 2 & 2 & 3 & 34 & 44 & +4 & $4+$ & + & + & 1 & 1 & 1 & + & + & 1 & + & + & +-4 & $\mathrm{~V}$ & 84 \\
\hline Elymus caninus (Pna, Qpp) & $\mathrm{C}$ & + & 1 & 1 & + & + & - & + & + & + & + & + & + & ++ & ++ & + & +- & - & - & - & - & + & + & + & + & + & - & +-1 & IV & 76 \\
\hline \multirow[t]{3}{*}{ Viburnum opulus (Ata) } & B1 & - & - & - & - & - & - & + & 1 & - & 1 & + & + & +1 & $1+$ & - & - & - & - & + & - & - & - & - & - & - & - & +-1 & II & 32 \\
\hline & B2 & - & - & - & - & - & + & + & 1 & + & + & + & + & +1 & $1+$ & + & + & - & & + & + & - & + & + & - & + & - & +-1 & III & 60 \\
\hline & S & - & - & - & - & - & + & + & 2 & + & 1 & + & + & +2 & $2+$ & + & + & - & & + & + & & + & + & - & + & - & +-2 & III & 60 \\
\hline \multirow[t]{3}{*}{ Frangula alnus (Ata, Qr, PQ) } & B1 & - & - & - & - & - & 1 & + & + & + & + & - & + & ++ & ++ & + & & + & + & + & - & - & - & - & - & - & - & +-1 & III & 48 \\
\hline & B2 & - & - & - & - & - & + & + & + & - & - & + & + & ++ & ++ & + & & ++ & + & - & + & & - & - & - & - & - & + & III & 44 \\
\hline & $S$ & - & - & - & - & - & 1 & + & + & + & + & + & + & ++ & ++ & + & + & + & + & + & + & - & - & - & - & - & - & +-1 & III & 56 \\
\hline Malus sylvestris (Qpp) & A2 & - & - & - & 1 & - & + & - & + & - & - & - & - & - & + & - & - & - & - & - & - & - & + & - & - & + & - & +-1 & II & 24 \\
\hline & B1 & - & - & + & - & - & - & + & - & - & - & - & + & +- & - & + & +- & - & - & - & - & - & - & - & - & - & - & + & I & 16 \\
\hline & B2 & - & - & + & - & - & - & + & + & - & - & + & + & +- & - - & & +- & - & - & - & - & - & - & - & - & - & ${ }^{-}$ & + & II & 24 \\
\hline & $S$ & - & - & + & 1 & - & + & + & + & - & - & + & + & + & + & + & + & - & - & - & - & - & + & - & - & + & - & +-1 & III & 44 \\
\hline
\end{tabular}


Kitaibelia 26(1): 49-76.

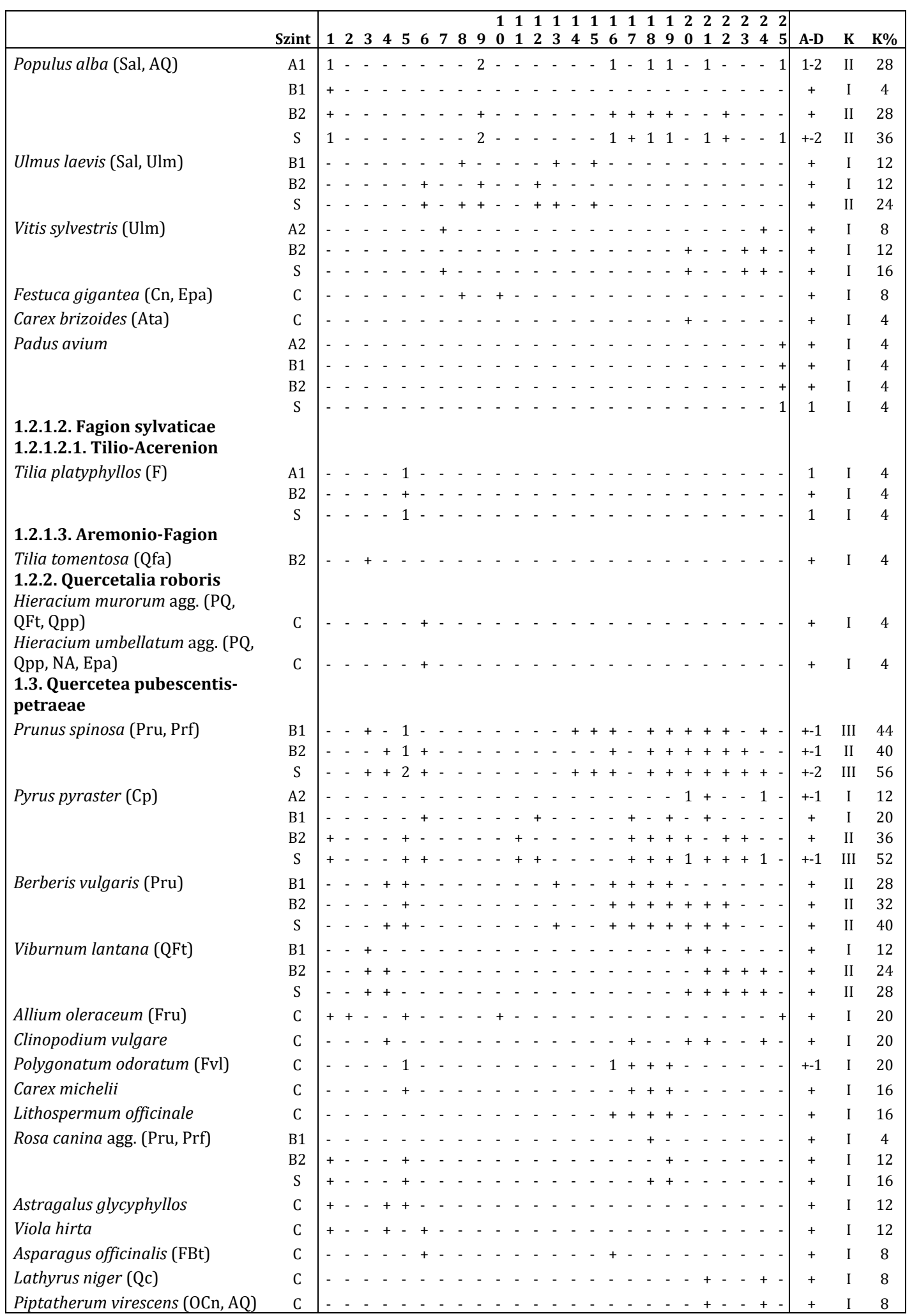


KEVEY (2021): A Duna-Tisza köze gyertyános-tölgyesei

\begin{tabular}{|c|c|c|c|c|c|c|c|c|c|c|c|c|c|c|c|c|c|c|c|c|c|c|c|c|c|c|c|c|c|c|}
\hline & Szint & 1 & 2 & 3 & 4 & 5 & 6 & 7 & 8 & 9 & & & & & & $\begin{array}{l}1 \\
5 \\
+\end{array}$ & 1 & & & & & $\begin{array}{l}2 \\
0\end{array}$ & 12 & & 2 & & $\begin{array}{l}2 \\
5\end{array}$ & A-D & $\mathbf{K}$ & K\% \\
\hline \multicolumn{31}{|l|}{ Buglossoides purpuro-coerulea } \\
\hline$(\mathrm{OCn}, \mathrm{AQ})$ & $\mathrm{C}$ & - & - & - & + & - & - & - & - & - & - & - & - & - & - & - & - & - & - - & - & - & - & - & - & - & - & - & + & I & 4 \\
\hline Doronicum hungaricum (AQ) & $\mathrm{C}$ & - & + & - & - & - & - & - & - & - & - & - & - & - & - & - & - & - & - & - & - & - & - & - & - & - & - & + & I & 4 \\
\hline Geranium divaricatum (GA) & $\mathrm{C}$ & + & - & - & - & - & - & - & - & - & - & - & - & - & - & - & - & - & - & - & - & - & - & - & - & - & - & + & I & 4 \\
\hline Hieracium sabaudum agg. (Qr) & $\mathrm{C}$ & - & - & - & - & - & + & - & - & - & - & - & - & - & - & - & - & - & - & - & - & - & - & - & - & - & - & + & I & 4 \\
\hline Inula salicina (MoA, Fvg) & $\mathrm{C}$ & - & - & - & - & - & + & - & - & - & - & - & - & - & - & - & - & - & - & - & - & - & - & - & - & - & - & + & I & 4 \\
\hline Lactuca quercina ssp. quercina & $\mathrm{C}$ & - & - & - & + & - & - & - & - & - & - & - & - & - & - & - & - & - & - & - & - & - & - & - & - & - & - & + & I & 4 \\
\hline $\begin{array}{l}\text { Vincetoxicum hirundinaria }(\mathrm{Fvl}) \\
\text { 1.3.1. Quercetalia cerridis }\end{array}$ & $\mathrm{C}$ & - & - & - & + & - & - & - & - & - & - & - & - & - & - & - & - & - & - & - & - & - & - & - & - & - & - & + & I & 4 \\
\hline Cerasus mahaleb & B1 & - & - & - & - & + & - & - & - & - & - & - & - & - & - & - & - & - & . & - & - & - & - & - & - & - & - & + & I & 4 \\
\hline & B2 & - & - & - & - & + & - & - & - & - & - & - & - & - & - & - & - & - & - & - & - & - & - & - & - & - & - & + & I & 4 \\
\hline & $S$ & - & - & - & - & + & - & - & - & - & - & - & - & - & - & - & - & - & - & - & - & - & - & - & - & - & - & + & I & 4 \\
\hline \multicolumn{31}{|l|}{ 1.3.1.1. Aceri tatarici-Quercion } \\
\hline Acer tataricum (Qpp) & $\mathrm{A} 2$ & - & + & - & 1 & - & 1 & - & - & - & - & - & - & - & - & - & - & - & 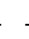 & - & - & 1 & 11 & 11 & 1 & 2 & - & +-2 & II & 32 \\
\hline & B1 & - & 1 & - & 1 & - & 1 & - & - & - & - & - & - & - & - & - & - & - & - & - & - & 2 & 11 & 11 & 1 & 2 & - & $1-2$ & II & 32 \\
\hline & B2 & + & 1 & + & + & - & + & - & - & + & - & - & - & - & - & - & - & - & - & - & - & 1 & + & + & + & + & - & +-1 & III & 44 \\
\hline & S & + & 2 & + & 2 & - & 2 & - & - & + & - & - & - & - & - & - & - & - & - & - & - & 2 & 22 & 22 & 2 & 3 & - & +-3 & III & 44 \\
\hline Melica altissima & $\mathrm{C}$ & - & + & - & + & - & - & - & - & - & - & - & - & - & - & - & - & - & . & - & - & - & - & - & - & - & - & + & I & 8 \\
\hline $\begin{array}{l}\text { Botrychium virginianum (Ai) } \\
\text { 2. Cypero-Phragmitea } \\
\text { 2.1. Phragmitetea } \\
\text { Carex acutiformis (Mag, Cgr, Moa, }\end{array}$ & C & - & - & - & - & - & - & - & - & - & - & - & - & - & - & - & - & - & - & - & - & - & - & - & - & - & + & + & I & 4 \\
\hline Sal, Ata) & C & - & - & - & - & - & - & - & - & - & - & - & - & - & - & + & - & - & - & - & - & + & - & - & + & - & - & + & I & 12 \\
\hline $\begin{array}{l}\text { Solanum dulcamara }(\mathrm{Cn}, \mathrm{Bia}, \mathrm{Spu}) \\
\text { Phragmites australis (Moa, FPe, }\end{array}$ & C & - & - & - & - & + & - & - & - & - & - & - & - & - & - & - & - & -+ & + & - & - & - & - & - & - & - & - & + & I & 8 \\
\hline $\begin{array}{l}\text { Spu, Ata) } \\
\text { 2.1.1. Magnocaricetalia } \\
\text { 2.1.1.1. Magnocaricion } \\
\text { 2.1.1.1.1. Caricenion gracilis }\end{array}$ & $\mathrm{C}$ & - & - & - & - & - & - & - & - & - & - & - & - & - & + & - & - & - & . & - & - & - & - & - & - & - & - & + & I & 4 \\
\hline $\begin{array}{l}\text { Carex acuta (Pte, Mag, Moa, Ata, Ai) } \\
\text { 3. Molinio-Arrhenatherea }\end{array}$ & C & - & - & - & - & - & - & - & - & - & - & - & - & - & - & - & - & - & . & - & - & - & + & - & - & - & - & + & I & 4 \\
\hline Colchicum autumnale (Moa) & $\mathrm{C}$ & - & - & - & - & - & + & + & - & + & - & - & + & - & + & + & - & - & - & 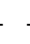 & - & - & - & - & - & - & - & + & II & 24 \\
\hline $\begin{array}{l}\text { Poa trivialis (Pte, Spu, Ata, Ai) } \\
\text { 3.1. Molinio-Juncetea } \\
\text { Deschampsia caespitosa (Des, Sal, }\end{array}$ & $\mathrm{C}$ & - & - & - & + & - & - & - & - & - & - & - & - & - & - & - & - & - - & 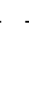 & - & - & - & - & - & - & - & + & + & I & 8 \\
\hline $\begin{array}{l}\text { Ata, Ai) } \\
\text { Symphytum officinale (Pte, Cn, }\end{array}$ & $\mathrm{C}$ & - & - & - & - & - & - & - & + & - & - & - & - & + & - - & - & - & - - & . & + & + & + & + & - & + & + & - & + & II & 32 \\
\hline Spu, Ata, Ai) & C & - & - & - & - & - & - & - & - & - & - & - & - & + & - & + & - & - - & - & - & - & - & - & - & - & -1 & 1 & +-1 & I & 12 \\
\hline $\begin{array}{l}\text { Veratrum album (Ata, Ai) } \\
\text { 3.1.1. Molinietalia coeruleae }\end{array}$ & $\mathrm{C}$ & - & - & - & - & - & - & + & - & - & - & - & - & - & - & - & - & - - & . & - & - & - & - & - & - & - & - & + & I & 4 \\
\hline $\begin{array}{l}\text { Angelica sylvestris (Mag, Ata, Ai) } \\
\text { 3.1.1.1. Deschampsion } \\
\text { caespitosae }\end{array}$ & $\mathrm{C}$ & - & - & - & - & - & - & + & + & + & + & + & + & + & + & + & - & - - & - & - & - & - & - & - & - & - & - & + & II & 36 \\
\hline $\begin{array}{l}\text { Galium rubioides (Alo, Qpp) } \\
\text { 3.2. Nardo-Callunetea } \\
\text { 3.2.1. Nardetalia } \\
\text { 3.3. Calluno-Ulicetea } \\
\text { 3.3.1. Vaccinio-Genistetalia } \\
\text { 3.3.1.1. Calluno-Genistion }\end{array}$ & C & - & - & - & - & - & - & - & - & - & - & - & - & - & - & - & - & - & & + & + & - & - & - & - & - & - & + & I & 8 \\
\hline $\begin{array}{l}\text { Betula pendula }(\mathrm{Qr}, \mathrm{APa}) \\
\text { 4. Festuco-Bromea } \\
\text { 4.1. Festuco-Brometea }\end{array}$ & $\mathrm{A} 1$ & - & - & - & - & - & - & - & - & - & - & - & - & - & - & - & - & - & & 1 & & - & - & - & - & - & - & 1 & I & 4 \\
\hline Arabis hirsuta (Qpp) & C & - & - & - & - & - & - & - & - & - & - & - & - & - & - & - & - & - & -1 & + & + & - & - & - & - & 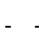 & - & + & I & 8 \\
\hline Muscari racemosum (Qpp) & $\mathrm{C}$ & - & - & - & - & - & - & - & - & + & - & - & - & - & - & - & - & - - & - & - & - & - & - & - & - & 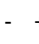 & + & + & I & 8 \\
\hline $\begin{array}{l}\text { Brachypodium pinnatum (Qpp) } \\
\text { 4.1.1. Festucetalia valesiacae } \\
\text { 4.1.1.1. Festucion rupicolae }\end{array}$ & $\mathrm{C}$ & - & - & - & - & - & - & - & - & - & - & - & - & - & - & - & & & & - & & - & - & & - & - & - & + & I & 4 \\
\hline Cynoglossum hungaricum (Qpp) & $\mathrm{C}$ & - & - & - & - & - & - & - & - & - & - & - & - & - & - & - & + & ++ & + & - & - & - & - & - & - & + & & + & I & 12 \\
\hline
\end{tabular}


Kitaibelia 26(1): 49-76.

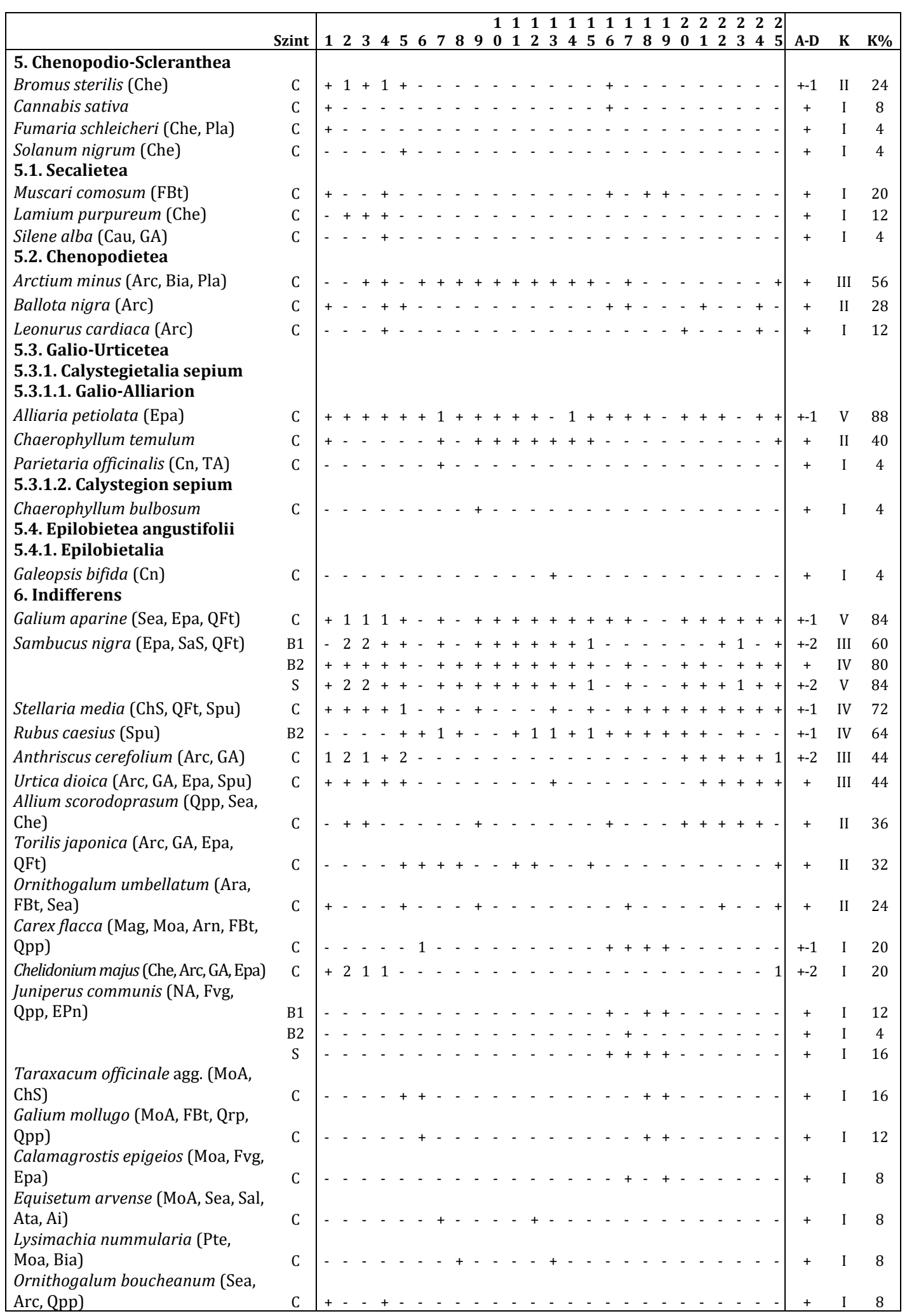


KEVEY (2021): A Duna-Tisza köze gyertyános-tölgyesei

\begin{tabular}{|c|c|c|c|c|c|c|c|c|c|c|c|c|c|c|c|c|c|c|c|c|c|c|c|c|c|c|c|c|c|}
\hline & Szint & 1 & 2 & 3 & 4 & 5 & 6 & 7 & 8 & 9 & $\begin{array}{l}\mathbf{1} \\
\mathbf{0}\end{array}$ & $\begin{array}{l}1 \\
1 \\
\end{array}$ & $\begin{array}{l}1 \\
2 \\
\end{array}$ & $\begin{array}{l}1 \\
3 \\
\end{array}$ & $\begin{array}{l}1 \\
4 \\
\end{array}$ & $\begin{array}{l}1 \\
5 \\
\end{array}$ & $\begin{array}{l}1 \\
6 \\
\end{array}$ & $\begin{array}{l}1 \\
7 \\
\end{array}$ & $\begin{array}{l}1 \\
8 \\
\end{array}$ & 9 & $\mathbf{0}$ & 1 & 2 & 3 & & 5 & A-D & $\mathbf{K}$ & $\mathbf{K} \%$ \\
\hline $\begin{array}{l}\text { Ajuga genevensis (Ara, FBt, Qpp) } \\
\text { Pimpinella saxifraga (MoA, FB, }\end{array}$ & $\mathrm{C}$ & - & - & - & - & - & - & - & - & - & - & - & - & - & - & - & - & - & - & - & + & - & - & - & - & - & + & I & 4 \\
\hline Qpp) & $\mathrm{C}$ & - & - & - & - & - & + & - & - & - & - & - & - & - & - & - & - & - & - & - & - & - & - & - & - & - & + & I & 4 \\
\hline $\begin{array}{l}\text { Poa bulbosa (FPe, FB, Sea, Che) } \\
\text { Ranunculus repens (Pte, MoA, }\end{array}$ & $\mathrm{C}$ & - & - & - & - & + & - & - & - & - & - & - & - & - & - & - & - & - & - & - & - & - & - & - & - & - & + & I & 4 \\
\hline ChS, Spu, Ata) & C & - & - & - & - & - & - & - & - & - & - & - & - & - & - & + & - & - & - & - & - & - & - & - & - & - & + & I & 4 \\
\hline $\begin{array}{l}\text { Securigea varia (Ara, FBt, Qpp) } \\
\text { Serratula tinctoria (MoA, Moa, }\end{array}$ & $\mathrm{C}$ & - & - & - & - & - & + & - & - & - & - & - & - & - & - & - & - & - & - & - & - & - & - & - & - & - & + & I & 4 \\
\hline $\begin{array}{l}\text { Qrp, Qpp, PQ) } \\
\text { 7. Adventiva }\end{array}$ & C & - & - & - & - & - & + & - & - & - & - & - & - & - & - & - & - & - & - & - & - & - & - & - & - & - & + & I & 4 \\
\hline Celtis occidentalis & A1 & 1 & - & - & - & - & - & - & - & - & - & - & - & - & - & - & - & - & - & - & - & - & - & - & - & - & 1 & I & 4 \\
\hline & A2 & 2 & - & - & 1 & - & - & - & - & - & - & - & - & - & - & - & - & - & - & - & - & - & - & - & - & + & +-2 & I & 12 \\
\hline & B1 & 2 & - & + & + & + & - & + & - & - & - & + & - & - & - & - & - & + & + & 1 & - & - & - & - & + & + & +-2 & III & 44 \\
\hline & B2 & 1 & - & + & + & + & + & + & - & - & + & - & + & - & - & + & + & + & + & 1 & - & - & + & - & - & + & +-1 & III & 60 \\
\hline & S & 3 & - & + & 1 & + & + & + & - & - & + & + & + & - & - & + & + & + & + & 2 & - & - & + & - & + & 1 & +-3 & IV & 68 \\
\hline Robinia pseudo-acacia & $\mathrm{A} 1$ & - & 1 & - & - & 1 & - & - & - & - & - & - & - & - & - & - & + & - & - & - & - & - & - & - & - & + & +-1 & I & 16 \\
\hline & A2 & - & - & + & + & 1 & - & - & - & - & - & - & - & - & + & - & + & 1 & - & - & - & - & - & - & - & 1 & +-1 & II & 28 \\
\hline & B1 & - & + & + & - & - & + & - & - & - & - & - & - & - & + & - & - & - & - & + & - & - & - & - & - & - & + & I & 20 \\
\hline & B2 & - & + & + & - & + & - & - & - & - & - & - & + & - & - & + & - & + & + & - & - & - & - & - & - & - & + & II & 28 \\
\hline & S & - & 1 & 1 & + & 2 & + & - & - & - & - & - & + & - & + & + & + & 1 & + & + & - & - & - & - & - & 1 & +-2 & III & 52 \\
\hline Padus serotina & A2 & - & - & - & - & - & - & - & - & - & - & - & - & - & - & - & + & - & - & - & - & - & - & - & - & - & + & I & 4 \\
\hline & B1 & - & + & + & - & - & - & - & - & - & - & - & - & - & - & - & + & + & + & - & - & - & - & - & - & - & + & I & 20 \\
\hline & B2 & - & + & - & - & - & - & - & - & - & - & - & - & - & - & - & + & + & + & + & - & - & - & - & - & - & + & I & 20 \\
\hline & $S$ & - & + & + & - & - & - & - & - & - & - & - & - & - & - & - & 1 & + & + & + & - & - & - & - & - & - & +-1 & II & 24 \\
\hline Ailanthus altissima & A2 & - & - & - & 1 & - & - & - & - & - & - & - & - & - & - & - & - & + & + & - & - & - & - & - & - & - & +-1 & I & 12 \\
\hline & B1 & - & - & - & - & - & - & - & - & - & - & - & - & - & - & - & + & - & - & - & - & - & - & - & - & - & + & I & 4 \\
\hline & B2 & - & - & - & + & - & - & - & - & - & - & - & - & - & - & - & + & + & + & - & - & - & - & - & - & - & + & I & 16 \\
\hline & $S$ & - & - & - & 1 & - & - & - & - & - & - & - & - & - & - & - & + & + & + & - & - & - & - & - & - & - & +-1 & I & 16 \\
\hline Fraxinus pennsylvanica & $\mathrm{A} 2$ & - & - & - & - & - & - & - & - & - & - & - & - & - & - & - & - & - & - & - & 1 & - & 1 & + & + & - & +-1 & I & 16 \\
\hline & B1 & - & - & - & - & - & - & - & - & - & - & - & - & - & - & - & - & - & - & - & 1 & - & + & - & + & - & +-1 & I & 12 \\
\hline & B2 & - & - & - & - & - & - & - & - & - & - & - & - & - & - & - & - & - & - & - & + & - & + & + & + & - & + & I & 16 \\
\hline & $S$ & - & - & - & - & - & - & - & - & - & - & - & - & - & - & - & - & - & - & - & 2 & - & 1 & + & 1 & - & +-2 & I & 16 \\
\hline Solidago canadensis & $\mathrm{C}$ & - & - & - & - & - & - & - & + & - & - & - & + & + & + & - & - & - & - & - & - & - & - & - & - & - & + & I & 16 \\
\hline Acer negundo & B1 & - & + & - & - & - & - & - & - & - & - & - & - & - & - & - & - & - & - & - & - & - & - & - & - & - & + & I & 4 \\
\hline & B2 & - & - & - & - & - & - & - & + & - & - & - & - & - & - & - & - & - & - & - & - & - & - & - & - & - & + & I & 4 \\
\hline & $S$ & - & + & - & - & - & - & - & + & - & - & - & - & - & - & - & - & - & - & - & - & - & - & - & - & - & + & I & 8 \\
\hline Asclepias syriaca & C & - & - & - & + & - & - & - & - & - & - & - & - & - & - & - & - & + & - & - & - & - & - & - & - & - & + & I & 8 \\
\hline Gleditsia triacanthos & B2 & - & - & - & - & - & + & - & - & - & - & - & - & - & - & - & - & - & - & - & - & + & - & - & - & - & + & I & 8 \\
\hline Impatiens parviflora & $\mathrm{C}$ & - & - & - & - & - & + & - & - & - & - & - & - & - & + & - & - & - & - & - & - & - & - & - & - & - & + & I & 8 \\
\hline Morus alba & A2 & - & - & - & - & + & - & - & - & - & - & - & - & - & - & - & - & - & - & - & - & - & - & - & - & - & + & I & 4 \\
\hline & B2 & - & - & - & + & + & - & - & - & - & - & - & - & - & - & - & - & - & - & - & - & - & - & - & - & - & + & I & 8 \\
\hline & S & - & - & - & + & + & - & - & - & - & - & - & - & - & - & - & - & - & - & - & - & - & - & - & - & - & + & I & 8 \\
\hline Quercus rubra & B2 & - & + & + & - & - & - & - & - & - & - & - & - & - & - & - & - & - & - & - & - & - & - & - & - & - & + & I & 8 \\
\hline Solidago gigantea & $\mathrm{C}$ & - & - & - & + & - & - & - & - & - & - & - & - & - & - & - & - & + & - & - & - & - & - & - & - & - & + & I & 8 \\
\hline Aesculus hippocastanum & B1 & - & - & - & - & - & - & - & - & - & - & - & + & 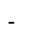 & - & - & - & - & - & - & - & - & - & - & - & - & + & I & 4 \\
\hline & B2 & - & - & - & - & - & - & - & - & - & - & - & + & - & - & - & - & - & - & - & - & - & - & - & - & - & + & I & 4 \\
\hline & S & - & - & - & - & - & - & - & - & - & - & - & + & - & - & - & - & - & - & - & - & - & - & - & - & - & + & I & 4 \\
\hline Juglans nigra & B2 & + & - & - & - & - & - & - & - & - & - & - & - & - & - & - & - & - & - & - & - & - & - & - & - & - & + & I & 4 \\
\hline Phytolacca americana & $\mathrm{C}$ & - & - & - & + & - & - & - & - & - & - & - & - & - & - & - & - & - & - & - & - & 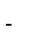 & - & - & - & - & + & I & 4 \\
\hline Syringa vulgaris & $\mathrm{B} 2$ & - & - & - & - & - & - & - & - & - & - & - & - & - & - & - & - & - & - & + & - & - & - & - & - & & + & I & 4 \\
\hline
\end{tabular}


Kitaibelia 26(1): 49-76.

2. táblázat Felvételi adatok I.

Table 2 Data of the relevés I.

\begin{tabular}{|l|c|c|c|c|c|c|c|c|c|c|c|c|c|}
\hline \multicolumn{1}{|c|}{ Kvadrát sorszáma } & $\mathbf{1}$ & $\mathbf{2}$ & $\mathbf{3}$ & $\mathbf{4}$ & $\mathbf{5}$ & $\mathbf{6}$ & $\mathbf{7}$ & $\mathbf{8}$ & $\mathbf{9}$ & $\mathbf{1 0}$ & $\mathbf{1 1}$ & $\mathbf{1 2}$ & $\mathbf{1 3}$ \\
\hline Kvadrát felvételi sorszáma & 16116 & 16591 & 16716 & 16717 & 16117 & 16588 & 16589 & 16718 & 16719 & 16727 & 16728 & 16720 & 16721 \\
Felvételi évszám 1. & 2011 & 2015 & 2015 & 2015 & 2012 & 2016 & 2015 & 2016 & 2015 & 2018 & 2018 & 2015 & 2015 \\
Felvételi időpont 1. & 06.15 & 06.02 & 06.02 & 06.02 & 06.15 & 04.19 & 05.30 & 04.25 & 05.31 & 04.29 & 04.29 & 05.31 & 05.30 \\
Felvételi évszám 2. & 2014 & 2016 & 2016 & 2016 & 2013 & 2016 & 2016 & 2016 & 2016 & 2018 & 2018 & 2016 & 2016 \\
Felvételi időpont 2. & 04.28 & 04.22 & 04.22 & 04.22 & 04.30 & 07.07 & 04.19 & 07.07 & 04.19 & 07.04 & 07.04 & 04.19 & 04.19 \\
Tengerszint feletti magasság & 133 & 122 & 122 & 120 & 117 & 107 & 109 & 110 & 111 & 106 & 104 & 104 & 108 \\
Kitettség & É & - & - & - & - & - & - & - & - & - & - & - & - \\
Lejtőszög (fok) & 5 & 0 & 0 & 0 & 0 & 0 & 0 & 0 & 0 & 0 & 0 & 0 & 0 \\
Felsőlombkoronaszint borítása (\%) & 70 & 65 & 60 & 65 & 70 & 75 & 85 & 80 & 75 & 80 & 80 & 75 & 80 \\
Felső lombkoronaszint & 27 & 28 & 27 & 28 & 23 & 22 & 25 & 28 & 27 & 25 & 32 & 30 & 27 \\
magassága (m) & 65 & 65 & 65 & 65 & 40 & 45 & 45 & 60 & 55 & 45 & 55 & 50 & 45 \\
Átlagos törzsátmérő (cm) & 40 & 40 & 40 & 40 & 25 & 25 & 25 & 30 & 20 & 30 & 20 & 25 & 30 \\
Alsó lombkoronaszint borítása (\%) & 18 & 20 & 20 & 20 & 15 & 17 & 15 & 20 & 20 & 18 & 20 & 18 & 15 \\
Alsólombkoronaszint magassága (m) & 30 & 35 & 35 & 35 & 60 & 40 & 40 & 30 & 50 & 50 & 50 & 60 & 50 \\
Cserjeszint borítása (\%) & 3 & 2,5 & 2 & 2,5 & 2,5 & 2,5 & 3,5 & 2,5 & 2,5 & 2 & 2,5 & 3 & 2,5 \\
Cserjeszint magassága (m) & 75 & 10 & 15 & 10 & 20 & 10 & 10 & 25 & 10 & 5 & 5 & 10 & 25 \\
Újulat borítása (\%) & 50 & 50 & 50 & 50 & 50 & 50 & 50 & 60 & 50 & 50 & 60 & 50 & 50 \\
Gyepszint borítása (\%) & 1600 & 1200 & 1200 & 1200 & 1600 & 1600 & 1600 & 1600 & 1200 & 1600 & 1600 & 1600 & 1600 \\
Felvételi terület nagysága (m²) & & & & &
\end{tabular}

\begin{tabular}{|c|c|c|c|c|c|c|c|c|c|c|c|c|}
\hline Kvadrát sorszáma & 14 & 15 & 16 & 17 & 18 & 19 & 20 & 21 & 22 & 23 & 24 & 25 \\
\hline Kvadrát felvételi sorszáma & 16722 & 16723 & 16592 & 16593 & 16713 & 16714 & 16590 & 16607 & 16608 & 16115 & 16715 & 7889 \\
\hline Felvételi évszám 1. & 2015 & 2015 & 2015 & 2015 & 2015 & 2015 & 2014 & 2014 & 2015 & 2014 & 2015 & 1999 \\
\hline Felvételi időpont 1. & 05.31 & 05.31 & 04.30 & 06.08 & 06.09 & 06.09 & 08.08 & 08.08 & 04.24 & 07.18 & 04.24 & 04.26 \\
\hline Felvételi évszám 2. & 2016 & 2016 & 2015 & 2016 & 2016 & 2016 & 2015 & 2015 & 2015 & 2015 & 2015 & 1999 \\
\hline Felvételi időpont 2. & 04.19 & 04.19 & 06.07 & 04.22 & 04.22 & 04.22 & 04.24 & 04.24 & 06.08 & 04.24 & 06.08 & 08.30 \\
\hline Tengerszint feletti magasság & 106 & 109 & 100 & 105 & 105 & 105 & 114 & 114 & 114 & 114 & 114 & 142 \\
\hline Kitettség & - & - & - & - & - & - & - & - & - & - & - & - \\
\hline Lejtőszög (fok) & 0 & 0 & 0 & 0 & 0 & 0 & 0 & 0 & 0 & 0 & 0 & 0 \\
\hline Felső lombkoronaszint borítása (\%) & 75 & 70 & 40 & 70 & 75 & 70 & 80 & 75 & 75 & 80 & 75 & 80 \\
\hline $\begin{array}{l}\text { Felső lombkoronaszint } \\
\text { magassága }(\mathrm{m})\end{array}$ & 28 & 28 & 27 & 30 & 28 & 28 & 25 & 25 & 28 & 25 & 30 & 28 \\
\hline Átlagos törzsátmérő (cm) & 45 & 45 & 80 & 60 & 60 & 60 & 65 & 55 & 65 & 60 & 65 & 70 \\
\hline Alsó lombkoronaszint borítása (\%) & 40 & 20 & 70 & 40 & 40 & 40 & 40 & 50 & 40 & 40 & 40 & 50 \\
\hline Alsó lombkoronaszint magassága (m) & 20 & 16 & 15 & 15 & 17 & 18 & 17 & 18 & 15 & 18 & 15 & 22 \\
\hline Cserjeszint borítása (\%) & 60 & 40 & 60 & 35 & 40 & 60 & 50 & 40 & 40 & 40 & 50 & 5 \\
\hline Cserjeszint magassága (m) & 2,5 & 2,5 & 2,5 & 2 & 2 & 2 & 2,5 & 3 & 3 & 3 & 3 & 2,5 \\
\hline Újulat borítása (\%) & 20 & 20 & 5 & 5 & 5 & 25 & 10 & 1 & 1 & 1 & 5 & 1 \\
\hline Gyepszint borítása (\%) & 50 & 50 & 20 & 10 & 5 & 5 & 30 & 5 & 10 & 10 & 10 & 50 \\
\hline Felvételi terület nagysága $\left(\mathrm{m}^{2}\right)$ & 1600 & 1200 & 1600 & 1200 & 1200 & 1200 & 1600 & 1200 & 1600 & 1600 & 1200 & 1600 \\
\hline
\end{tabular}


KEVEY (2021): A Duna-Tisza köze gyertyános-tölgyesei

3. táblázat Felvételi adatok II.

Table 3 Data of the relevés II.

\begin{tabular}{|c|c|c|c|c|c|c|}
\hline Sorszám & Település & Dülő & Koordináták & $\begin{array}{l}\text { Alap- } \\
\text { kőzet }\end{array}$ & $\begin{array}{l}\text { Talaj- } \\
\text { típus }\end{array}$ & Szerző \\
\hline 1 & Szentmártonkáta & Park-erdő & N 472 $26^{\prime} 54.37^{\prime \prime} /$ E $19^{\circ} 40^{\prime} 42.80^{\prime \prime}$ & \multirow{25}{*}{$\begin{array}{l}\text { y્y } \\
0 \\
E \\
0 \\
\text { E }\end{array}$} & \multirow{25}{*}{ 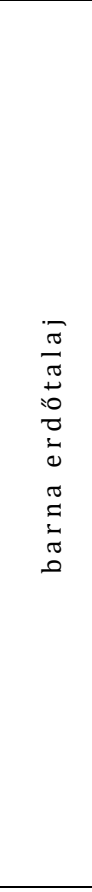 } & \multirow{25}{*}{ 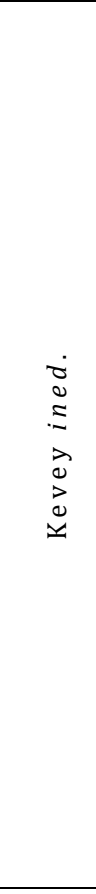 } \\
\hline 2 & Csévharaszt & Pótharaszti-Nagy-erdő & N 4715' 56.01" / E 19²3' 09.95" & & & \\
\hline 3 & Csévharaszt & Pótharaszti-Nagy-erdő & N $47^{\circ} 16^{\prime} 00.24^{\prime \prime} /$ E $19^{\circ} 23^{\prime} 07.45^{\prime \prime}$ & & & \\
\hline 4 & Csévharaszt & Pótharaszti-Nagy-erdő & N 471' $52.30^{\prime \prime}$ / E $19^{\circ} 22^{\prime} 49.79^{\prime \prime}$ & & & \\
\hline 5 & Tatárszentgyörgy & Göböly-erdő & N 4707' 59.16" / E 19²3' 54.27" & & & \\
\hline 6 & Ócsa & Nagy-erdő & N 47 15'26.36" / E 19 14' 26.65" & & & \\
\hline 7 & Ócsa & Nagy-erdő & N 47 15' 56.43" / E 19¹3' 51.28" & & & \\
\hline 8 & Ócsa & Nagy-erdő & N 4715' 42.05" / E 19¹4' 09.62" & & & \\
\hline 9 & Ócsa & Nagy-erdő & N 47 15' 29.37" / E 19 14' 51.30" & & & \\
\hline 10 & Ócsa & Nagy-erdő & N $47^{\circ} 15^{\prime} 47.58^{\prime \prime} /$ E $19^{\circ} 13^{\prime} 50.00^{\prime \prime}$ & & & \\
\hline 11 & Ócsa & Nagy-erdő & N 4715' 46.48" / E $19^{\circ} 13^{\prime} 54.61^{\prime \prime}$ & & & \\
\hline 12 & Ócsa & Nagy-erdő & 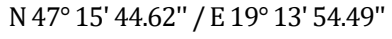 & & & \\
\hline 13 & Ócsa & Nagy-erdő & N $47^{\circ} 15^{\prime} 40.11^{\prime \prime} /$ E $19^{\circ} 14^{\prime} 07.20^{\prime \prime}$ & & & \\
\hline 14 & Ócsa & Nagy-erdő & N 4715' 48.97" / E 19¹3' 52.40" & & & \\
\hline 15 & Ócsa & Nagy-erdő & N 4715' 52.60" / E 19¹3' 51.98" & & & \\
\hline 16 & Kunadacs & Birkajárási-Új-erdő & N 46 59'08.98" / E $19^{\circ} 20^{\prime} 08.59^{\prime \prime}$ & & & \\
\hline 17 & Kunadacs & Birkajárási-Új-erdő & N 465 $57^{\prime} 53.65^{\prime \prime} /$ E $19^{\circ} 20^{\prime} 44.49^{\prime \prime}$ & & & \\
\hline 18 & Kunadacs & Birkajárási-Új-erdő & N 465' 55.31" / E $19^{\circ} 20^{\prime} 43.10^{\prime \prime}$ & & & \\
\hline 19 & Kunadacs & Birkajárási-Új-erdő & N 46 $57^{\prime} 58.52^{\prime \prime} /$ E $19^{\circ} 20^{\prime} 38.97^{\prime \prime}$ & & & \\
\hline 20 & Kunbaracs & Búhegyi-erdő & N 46 58' 34.29" / E 19²2' 38.06" & & & \\
\hline 21 & Kunbaracs & Búhegyi-erdő & N 46 58' 33.10" / E $19^{\circ} 22^{\prime} 35.01^{\prime \prime}$ & & & \\
\hline 22 & Kunbaracs & Búhegyi-erdő & N 46 58' 34.06" / E 19²2' 35.66" & & & \\
\hline 23 & Kunbaracs & Búhegyi-erdő & N 46 58' 32.21" / E 19²2' 38.71" & & & \\
\hline 24 & Kunbaracs & Búhegyi-erdő & N 46 58' 33.76" / E 19²2' 31.73" & & & \\
\hline 25 & Kiskunhalas & Holdrutás-erdő & N 462 21'33.28" / E 19²3' 39.93" & & & \\
\hline
\end{tabular}

4. táblázat Homoki gyertyános-tölgyesek

Table 4 Lowland oak-hornbeam forests on sand

D-T: Duna-Tisza köze (Kevey ined.: 25 felv.)

Mf: Mezőföld (KeVEY \& LENDVAI 2015: 25 felv.)

Ny: Nyírség (Kevey et al. 2017: 25 felv.)

Ba: Bakonyalja (KeVEY 2014: 10 felv.)

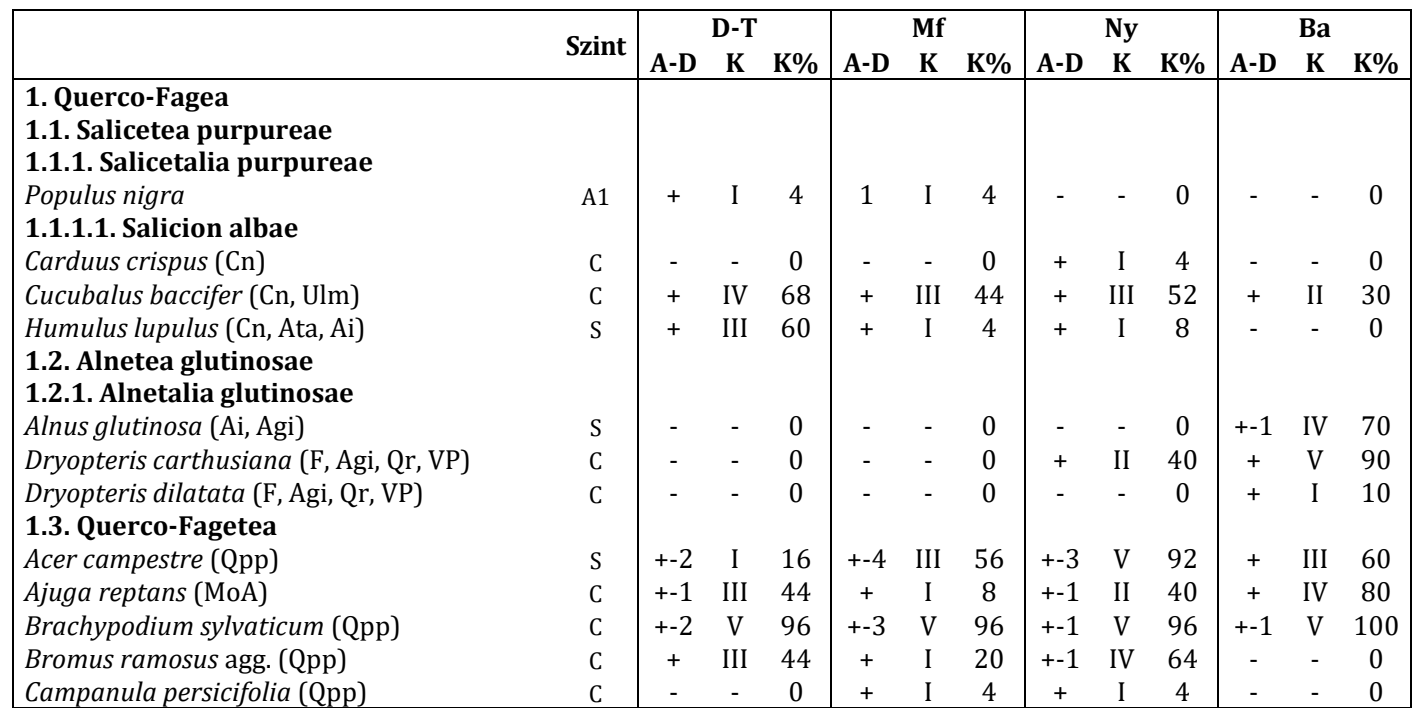


Kitaibelia 26(1): 49-76.

\begin{tabular}{|c|c|c|c|c|c|c|c|c|c|c|c|c|c|}
\hline & \multirow{2}{*}{ Szint } & \multicolumn{3}{|c|}{ D-T } & \multicolumn{3}{|c|}{ Mf } & \multicolumn{3}{|c|}{$\mathrm{Ny}$} & \multicolumn{3}{|c|}{ Ba } \\
\hline & & A-D & $\mathbf{K}$ & $\mathbf{K} \%$ & A-D & $\mathbf{K}$ & $\mathbf{K} \%$ & A-D & $\mathbf{K}$ & $\mathbf{K} \%$ & A-D & $\mathbf{K}$ & $\mathbf{K} \%$ \\
\hline Campanula trachelium (Epa, Cp) & $\mathrm{C}$ & + & II & 36 & + & II & 28 & - & - & 0 & + & II & 30 \\
\hline Carex divulsa & $\mathrm{C}$ & + & I & 8 & + & III & 60 & + & III & 52 & + & III & 50 \\
\hline Carex spicata (Qpp, Epa) & $\mathrm{C}$ & - & - & 0 & - & - & 0 & + & I & 16 & - & - & 0 \\
\hline Cephalanthera damasonium (Qpp) & $\mathrm{C}$ & + & I & 12 & + & I & 8 & - & - & 0 & - & - & 0 \\
\hline Clematis vitalba (Qpp) & S & + & $\mathrm{I}$ & 20 & +-2 & V & 96 & + & I & 8 & + & III & 60 \\
\hline Convallaria majalis (Qpp) & $\mathrm{C}$ & +-2 & IV & 72 & +-3 & IV & 76 & +-3 & $\mathrm{~V}$ & 88 & + & I & 10 \\
\hline Cornus sanguinea (Qpp) & S & +-2 & $\mathrm{~V}$ & 84 & +-2 & V & 96 & +-1 & IV & 68 & +-2 & II & 40 \\
\hline Corylus avellana (Qpp) & $\mathrm{S}$ & +-3 & II & 28 & +-4 & IV & 76 & +-2 & IV & 64 & +-2 & $\mathrm{~V}$ & 90 \\
\hline Crataegus laevigata & B1 & - & - & 0 & - & - & 0 & - & - & 0 & + & I & 10 \\
\hline Crataegus monogyna (Qpp) & S & +-3 & $\mathrm{~V}$ & 100 & +-2 & V & 96 & +-2 & $\mathrm{~V}$ & 100 & +-2 & IV & 70 \\
\hline Dactylis polygama (Qpp, Cp) & $\mathrm{C}$ & +-1 & V & 84 & +-1 & V & 88 & +-1 & III & 56 & +-1 & II & 40 \\
\hline Euonymus europaeus (Qpp) & S & +-1 & V & 100 & +-2 & V & 100 & + & $\mathrm{V}$ & 100 & + & $\mathrm{V}$ & 100 \\
\hline Fallopia dumetorum (Qpp, GA) & S & + & IV & 64 & + & V & 84 & + & IV & 68 & +-2 & IV & 80 \\
\hline Fragaria vesca (Qpp, Epa) & $\mathrm{C}$ & - & - & 0 & + & III & 52 & + & II & 28 & + & IV & 80 \\
\hline Fraxinus excelsior (Qpp, TA) & S & - & - & 0 & +-3 & III & 44 & - & - & 0 & +-2 & II & 40 \\
\hline Galeopsis pubescens (Qpp, Еpa) & $\mathrm{C}$ & + & I & 12 & + & IV & 76 & + & IV & 80 & + & IV & 80 \\
\hline Geranium robertianum (Еpa) & $\mathrm{C}$ & + & IV & 64 & + & $\mathrm{V}$ & 92 & +-2 & $\mathrm{~V}$ & 100 & +-2 & $\mathrm{~V}$ & 90 \\
\hline Geum urbanum (Еpa, Cp, Qpp) & $\mathrm{C}$ & + & V & 84 & +-1 & V & 96 & + & $\mathrm{V}$ & 96 & + & $\mathrm{V}$ & 100 \\
\hline Heracleum sphondylium (Qpp, MoA) & $\mathrm{C}$ & + & II & 36 & + & IV & 68 & + & I & 12 & + & IV & 80 \\
\hline Hypericum hirsutum (Qpp) & $\mathrm{C}$ & - & - & 0 & + & I & 4 & + & I & 4 & - & - & 0 \\
\hline Hypericum montanum & $\mathrm{C}$ & - & - & 0 & - & - & 0 & - & - & 0 & + & I & 10 \\
\hline Lapsana communis (Qpp, GA, Epa) & $\mathrm{C}$ & + & III & 56 & + & IV & 80 & + & $\mathrm{V}$ & 92 & + & IV & 70 \\
\hline Ligustrum vulgare (Cp, Qpp) & $\mathrm{S}$ & +-4 & V & 100 & +-2 & V & 100 & +-2 & $\mathrm{~V}$ & 84 & +-1 & $\mathrm{~V}$ & 100 \\
\hline Loranthus europaeus & A1 & - & - & 0 & +-1 & II & 36 & + & I & 20 & - & - & 0 \\
\hline Melampyrum nemorosum (Cp, Qpp) & $\mathrm{C}$ & - & - & 0 & - & - & 0 & + & I & 16 & - & - & 0 \\
\hline Melica nutans (Qpp) & $\mathrm{C}$ & - & - & 0 & + & I & 4 & - & - & 0 & + & II & 40 \\
\hline Melica uniflora (Cp, Qpp) & $\mathrm{C}$ & - & - & 0 & - & - & 0 & - & - & 0 & + & I & 10 \\
\hline Mycelis muralis & $\mathrm{C}$ & + & II & 32 & + & II & 28 & + & IV & 76 & + & IV & 80 \\
\hline Neottia nidus-avis (F, Qpp) & $\mathrm{C}$ & - & - & 0 & + & I & 8 & + & I & 20 & + & I & 20 \\
\hline Platanthera bifolia (Qpp, PQ, NA, Moa) & $\mathrm{C}$ & - & - & 0 & + & I & 20 & + & $\mathrm{I}$ & 20 & + & I & 10 \\
\hline Poa nemoralis (Qpp) & $\mathrm{C}$ & +-1 & II & 32 & + & III & 48 & + & III & 48 & + & I & 10 \\
\hline Polygonatum latifolium (Qpp) & $\mathrm{C}$ & +-3 & V & 96 & +-1 & V & 96 & +-3 & III & 56 & + & II & 40 \\
\hline Populus tremula (Qr, Qc, Ber) & S & + & $\mathrm{I}$ & 16 & +-2 & III & 60 & +-2 & I & 20 & +-1 & I & 20 \\
\hline Quercus robur (Ai, Cp, Qpp) & $\mathrm{S}$ & $3-5$ & V & 100 & $1-5$ & V & 100 & $1-4$ & $\mathrm{~V}$ & 100 & $1-4$ & V & 100 \\
\hline Ranunculus auricomus agg. (MoA) & $\mathrm{C}$ & - & - & 0 & - & - & 0 & + & II & 24 & - & - & 0 \\
\hline Ranunculus ficaria & $\mathrm{C}$ & +-2 & III & 48 & +-4 & IV & 68 & +-4 & $\mathrm{~V}$ & 96 & $1-4$ & V & 100 \\
\hline Rhamnus catharticus (Qpp, Pru) & S & +-2 & IV & 76 & + & IV & 76 & + & II & 36 & - & - & 0 \\
\hline Scrophularia nodosa (GA, Epa) & $\mathrm{C}$ & + & III & 44 & + & III & 60 & + & IV & 64 & + & IV & 70 \\
\hline Smyrnium perfoliatum (GA) & $\mathrm{C}$ & - & - & 0 & +-2 & II & 24 & - & - & 0 & - & - & 0 \\
\hline Staphylea pinnata (Cp, TA) & $\mathrm{S}$ & - & - & 0 & 1 & I & 4 & - & - & 0 & - & - & 0 \\
\hline Symphytum tuberosum (Cp, Qpp) & $\mathrm{C}$ & + & I & 12 & - & - & 0 & + & II & 24 & +-1 & $\mathrm{~V}$ & 100 \\
\hline Tilia cordata (Cp, Qpp) & S & - & - & 0 & + & I & 12 & +-2 & II & 40 & +-3 & III & 60 \\
\hline Veronica chamaedrys (Qpp, Ara) & $\mathrm{C}$ & + & I & 4 & - & - & 0 & + & III & 44 & + & III & 50 \\
\hline Veronica sublobata & $\mathrm{C}$ & +-2 & IV & 72 & +-1 & IV & 76 & +-1 & II & 36 & + & II & 30 \\
\hline Vicia dumetorum (Qpp) & $\mathrm{C}$ & - & - & 0 & - & - & 0 & + & $\mathrm{I}$ & 8 & - & - & 0 \\
\hline Viola mirabilis (F, Qpp) & $\mathrm{C}$ & - & - & 0 & - & - & 0 & +-2 & II & 40 & + & III & 50 \\
\hline Viola odorata & $\mathrm{C}$ & - & - & 0 & - & - & 0 & - & - & 0 & + & I & 20 \\
\hline $\begin{array}{l}\text { Viola suavis s.l. (Qpp) } \\
\text { 1.3.1. Fagetalia sylvaticae }\end{array}$ & $\mathrm{C}$ & +-2 & III & 60 & +-2 & III & 56 & + & II & 36 & + & III & 60 \\
\hline Acer platanoides (TA) & S & + & I & 16 & + & I & 4 & - & - & 0 & - & - & 0 \\
\hline Acer pseudo-platanus (TA) & $\mathrm{S}$ & + & I & 20 & - & - & 0 & + & I & 4 & + & III & 60 \\
\hline Aconitum vulparia & $\mathrm{C}$ & - & - & 0 & - & - & 0 & - & - & 0 & + & I & 10 \\
\hline Actaea spicata (EuF, TA) & $\mathrm{C}$ & - & - & 0 & - & - & 0 & + & II & 40 & - & - & 0 \\
\hline Aegopodium podagraria (Ai, Cp) & $\mathrm{C}$ & - & - & 0 & - & - & 0 & + & $\mathrm{I}$ & 4 & +-1 & IV & 70 \\
\hline Anemone ranunculoides & $\mathrm{C}$ & + & I & 12 & + & I & 4 & 1 & I & 4 & +-2 & III & 60 \\
\hline Arum orientale & $\mathrm{C}$ & +-1 & I & 8 & +-1 & II & 32 & - & - & 0 & - & - & 0 \\
\hline Asarum europaeum & $\mathrm{C}$ & - & - & 0 & 1 & $\mathrm{I}$ & 4 & - & - & 0 & - & - & 0 \\
\hline Athyrium filix-femina (Qr, VP) & $\mathrm{C}$ & - & - & 0 & - & - & 0 & +-1 & II & 40 & +-1 & IV & 80 \\
\hline Cardamine bulbifera & $\mathrm{C}$ & - & - & 0 & +-3 & II & 28 & +-4 & III & 44 & 3 & I & 10 \\
\hline Cardamine impatiens & $\mathrm{C}$ & - & - & 0 & - & - & 0 & + & I & 16 & + & IV & 80 \\
\hline
\end{tabular}


KEVEY (2021): A Duna-Tisza köze gyertyános-tölgyesei

\begin{tabular}{|c|c|c|c|c|c|c|c|c|c|c|c|c|c|}
\hline & \multirow{2}{*}{ Szint } & \multicolumn{3}{|c|}{ D-T } & \multicolumn{3}{|c|}{ Mf } & \multicolumn{3}{|c|}{ Ny } & \multicolumn{3}{|c|}{ Ba } \\
\hline & & A-D & $\mathbf{K}$ & $\mathbf{K} \%$ & A-D & $\mathbf{K}$ & $\mathbf{K} \%$ & A-D & $\mathbf{K}$ & $\mathbf{K} \%$ & A-D & $\mathbf{K}$ & $\mathbf{K} \%$ \\
\hline Carex sylvatica & $\mathrm{C}$ & + & I & 4 & +-1 & II & 40 & +-1 & IV & 72 & +-1 & $\mathrm{~V}$ & 90 \\
\hline Carpinus betulus (Cp) & $\mathrm{S}$ & $2-5$ & $\mathrm{~V}$ & 100 & $2-5$ & V & 100 & $2-5$ & $\mathrm{~V}$ & 100 & $3-5$ & V & 100 \\
\hline Cerasus avium (Cp) & S & +-1 & I & 12 & + & II & 28 & +-2 & $\mathrm{~V}$ & 96 & +-2 & V & 90 \\
\hline Chaerophyllum aromaticum (FiC) & $\mathrm{C}$ & - & - & 0 & - & - & 0 & + & I & 12 & - & - & 0 \\
\hline Circaea lutetiana (Ai) & $\mathrm{C}$ & +-1 & $\mathrm{I}$ & 16 & +-2 & IV & 64 & +-2 & $\mathrm{~V}$ & 96 & +-1 & $\mathrm{~V}$ & 100 \\
\hline Corydalis cava & $\mathrm{C}$ & + & I & 4 & +-5 & II & 24 & +-3 & III & 44 & - & - & 0 \\
\hline Corydalis intermedia & $\mathrm{C}$ & - & - & 0 & - & - & 0 & - & - & 0 & + & I & 10 \\
\hline Corydalis pumila (Cp, Qpp) & $\mathrm{C}$ & - & - & 0 & +-1 & II & 24 & - & - & 0 & + & I & 10 \\
\hline Corydalis solida & $\mathrm{C}$ & - & - & 0 & - & - & 0 & +-1 & I & 16 & - & - & 0 \\
\hline Dryopteris filix-mas & $\mathrm{C}$ & - & - & 0 & + & I & 4 & +-1 & IV & 80 & + & IV & 80 \\
\hline Epipactis helleborine agg. & $\mathrm{C}$ & + & II & 32 & + & I & 20 & + & III & 52 & + & $\mathrm{I}$ & 10 \\
\hline Epipactis microphylla & $\mathrm{C}$ & + & I & 4 & - & - & 0 & - & - & 0 & - & - & 0 \\
\hline Fagus sylvatica (EuF) & A1 & 1 & I & 4 & - & - & 0 & - & - & 0 & + & I & 10 \\
\hline Gagea lutea (Ai, Cp) & $\mathrm{C}$ & - & - & 0 & + & I & 8 & - & - & 0 & - & - & 0 \\
\hline Galeobdolon luteum & $\mathrm{C}$ & + & I & 4 & - & - & 0 & - & - & 0 & +-2 & II & 40 \\
\hline Galeopsis speciosa (Epn, Ai) & $\mathrm{C}$ & - & - & 0 & - & - & 0 & - & - & 0 & + & I & 10 \\
\hline Galium odoratum & $\mathrm{C}$ & - & - & 0 & $1-4$ & II & 28 & +-3 & III & 44 & +-1 & IV & 80 \\
\hline Galium sylvaticum (Cp, Qr, PQ) & $\mathrm{C}$ & - & - & 0 & - & - & 0 & - & - & 0 & + & I & 10 \\
\hline Glechoma hirsuta (Cp) & $\mathrm{C}$ & - & - & 0 & +-1 & II & 28 & + & $\mathrm{I}$ & 4 & + & I & 20 \\
\hline Hedera helix & S & +-5 & I & 16 & + & II & 24 & +-2 & III & 52 & +-1 & IV & 70 \\
\hline Isopyrum thalictroides & $\mathrm{C}$ & - & - & 0 & + & I & 4 & - & - & 0 & - & - & 0 \\
\hline Knautia drymeia (Cp) & $\mathrm{C}$ & - & - & 0 & - & - & 0 & - & - & 0 & +-1 & $\mathrm{~V}$ & 100 \\
\hline Lilium martagon (QFt, Qpp) & $\mathrm{C}$ & - & - & 0 & - & - & 0 & + & I & 12 & - & - & 0 \\
\hline Listera ovata (Ata, Ai) & $\mathrm{C}$ & +-1 & I & 8 & 1 & I & 8 & + & II & 24 & - & - & 0 \\
\hline Maianthemum bifolium (Qr) & $\mathrm{C}$ & - & - & 0 & - & - & 0 & + & I & 8 & + & I & 20 \\
\hline Mercurialis perennis & $\mathrm{C}$ & 2 & I & 4 & - & - & 0 & - & - & 0 & +-1 & II & 30 \\
\hline Milium effusum & $\mathrm{C}$ & - & - & 0 & 1 & I & 4 & + & IV & 80 & - & - & 0 \\
\hline Moehringia trinervia & $\mathrm{C}$ & + & III & 48 & + & IV & 80 & +-1 & $\mathrm{~V}$ & 100 & + & $\mathrm{V}$ & 100 \\
\hline Myosotis sparsiflora (GA, Cp) & $\mathrm{C}$ & - & - & 0 & + & I & 8 & - & - & 0 & - & - & 0 \\
\hline Oxalis acetosella (EuF, $\mathrm{VP})$ & $\mathrm{C}$ & - & - & 0 & - & - & 0 & - & - & 0 & + & III & 50 \\
\hline Paris quadrifolia (Ata, Ai) & $\mathrm{C}$ & +-1 & II & 40 & - & - & 0 & - & - & 0 & + & III & 50 \\
\hline Polygonatum multiflorum (QFt) & $\mathrm{C}$ & +-1 & II & 28 & - & - & 0 & +-1 & $\mathrm{~V}$ & 100 & +-1 & V & 100 \\
\hline Primula vulgaris (AF) & $\mathrm{C}$ & - & - & 0 & - & - & 0 & - & - & 0 & +-1 & V & 100 \\
\hline Pulmonaria officinalis & $\mathrm{C}$ & - & - & 0 & + & $\mathrm{I}$ & 4 & + & II & 24 & +-1 & III & 50 \\
\hline Rubus hirtus (Epa, SaS) & B2 & - & - & 0 & - & - & 0 & - & - & 0 & + & II & 30 \\
\hline Salvia glutinosa & $\mathrm{C}$ & - & - & 0 & - & - & 0 & +-2 & II & 28 & - & - & 0 \\
\hline Sanicula europaea & $\mathrm{C}$ & - & - & 0 & +-1 & II & 24 & + & III & 44 & + & III & 50 \\
\hline Scilla vindobonensis (Ai, Cp) & $\mathrm{C}$ & - & - & 0 & 1 & I & 4 & - & - & 0 & - & - & 0 \\
\hline Stachys sylvatica (Epa) & $\mathrm{C}$ & - & - & 0 & +-1 & V & 88 & +-1 & $\mathrm{~V}$ & 100 & +-1 & V & 100 \\
\hline Stellaria holostea (Cp) & $\mathrm{C}$ & - & - & 0 & + & I & 4 & - & - & 0 & - & - & 0 \\
\hline Ulmus glabra (TA) & $\mathrm{S}$ & 1 & I & 4 & +-1 & I & 16 & + & I & 8 & + & III & 60 \\
\hline Vinca minor $(\mathrm{Cp})$ & $\mathrm{C}$ & - & - & 0 & - & - & 0 & + & I & 4 & - & - & 0 \\
\hline Viola reichenbachiana & $\mathrm{C}$ & +-1 & II & 40 & + & II & 36 & +-1 & $\mathrm{~V}$ & 100 & +-1 & $\mathrm{~V}$ & 90 \\
\hline $\begin{array}{l}\text { Viola riviniana }(\mathrm{Qr}, \mathrm{PQ}) \\
\text { 1.3.1.1. Alnion incanae }\end{array}$ & $\mathrm{C}$ & + & I & 12 & - & - & 0 & - & - & 0 & - & - & 0 \\
\hline Carex brizoides (Ata) & $\mathrm{C}$ & + & I & 4 & - & - & 0 & + & I & 4 & - & - & 0 \\
\hline Carex remota & $\mathrm{C}$ & - & - & 0 & - & - & 0 & + & I & 20 & - & - & 0 \\
\hline Elymus caninus (Pna, Qpp) & $\mathrm{C}$ & +-1 & IV & 76 & + & II & 40 & +-1 & II & 40 & - & - & 0 \\
\hline Equisetum hyemale $(\mathrm{F})$ & $\mathrm{C}$ & - & - & 0 & + & I & 8 & - & - & 0 & - & - & 0 \\
\hline Festuca gigantea (Cn, Epa) & $\mathrm{C}$ & + & I & 8 & + & II & 40 & + & II & 32 & + & II & 40 \\
\hline Frangula alnus (Ata, Qr, PQ) & $\mathrm{S}$ & +-1 & III & 56 & + & III & 44 & + & II & 28 & + & II & 40 \\
\hline Fraxinus angustifolia ssp. danubialis (Ata) & $\mathrm{S}$ & +-4 & $\mathrm{~V}$ & 84 & +-2 & I & 8 & +-4 & IV & 76 & - & - & 0 \\
\hline Impatiens noli-tangere (Sal) & $\mathrm{C}$ & - & - & 0 & - & - & 0 & +-1 & II & 28 & +-2 & IV & 70 \\
\hline Malus sylvestris (Qpp) & $\mathrm{S}$ & +-1 & III & 44 & + & III & 48 & +-1 & II & 36 & + & III & 50 \\
\hline Padus avium & $\mathrm{S}$ & 1 & $\mathrm{I}$ & 4 & +-1 & I & 12 & + & I & 8 & - & - & 0 \\
\hline Populus $\times$ canescens (Sal, AQ) & $\mathrm{A} 1$ & - & - & 0 & + & I & 4 & - & - & 0 & - & - & 0 \\
\hline Populus alba (Sal, AQ) & $\mathrm{S}$ & +-2 & II & 36 & +-4 & III & 44 & +-2 & I & 20 & - & - & 0 \\
\hline Ribes rubrum ssp. sylvestre & $\mathrm{S}$ & - & - & 0 & + & I & 16 & + & $\mathrm{I}$ & 20 & + & I & 10 \\
\hline Rumex sanguineus (Epa, Pna) & $\mathrm{C}$ & - & - & 0 & + & II & 24 & + & III & 48 & + & I & 10 \\
\hline Ulmus laevis (Sal, Ulm) & $\mathrm{S}$ & + & II & 24 & + & $\mathrm{I}$ & 4 & +-2 & II & 40 & - & - & 0 \\
\hline
\end{tabular}


Kitaibelia 26(1): 49-76.

\begin{tabular}{|c|c|c|c|c|c|c|c|c|c|c|c|c|c|}
\hline & \multirow{2}{*}{ Szint } & \multicolumn{3}{|c|}{ D-T } & \multicolumn{3}{|c|}{ Mf } & \multicolumn{3}{|c|}{$\mathrm{Ny}$} & \multicolumn{3}{|c|}{ Ba } \\
\hline & & A-D & $\mathbf{K}$ & $\mathbf{K} \%$ & A-D & $\mathbf{K}$ & $\mathbf{K} \%$ & A-D & $\mathbf{K}$ & $\mathbf{K} \%$ & A-D & $\mathbf{K}$ & $\mathbf{K} \%$ \\
\hline Viburnum opulus (Ata) & $S$ & +-2 & III & 60 & + & III & 52 & + & III & 56 & + & III & 50 \\
\hline Vitis sylvestris (Ulm) & $\mathrm{S}$ & + & I & 16 & + & II & 24 & + & I & 8 & - & - & 0 \\
\hline \multicolumn{14}{|l|}{$\begin{array}{l}\text { 1.3.1.2. Fagion sylvaticae } \\
\text { 1.3.1.2.1. Tilio-Acerenion }\end{array}$} \\
\hline Geranium lucidum (GA) & $\mathrm{C}$ & - & - & 0 & + & I & 16 & - & - & 0 & - & - & 0 \\
\hline Polystichum aculeatum & $\mathrm{C}$ & - & - & 0 & + & I & 4 & - & - & 0 & - & - & 0 \\
\hline Tilia platyphyllos (F) & $\mathrm{S}$ & 1 & I & 4 & +-1 & II & 28 & - & - & 0 & - & - & 0 \\
\hline \multicolumn{14}{|l|}{ 1.3.1.3. Aremonio-Fagion } \\
\hline Lonicera caprifolium (OCn) & B2 & - & - & 0 & + & I & 4 & - & - & 0 & - & - & 0 \\
\hline Tilia tomentosa $(\mathrm{Qfa})$ & $\mathrm{S}$ & + & I & 4 & 3 & I & 4 & +-1 & II & 32 & - & - & 0 \\
\hline \multicolumn{14}{|l|}{ 1.3.2. Quercetalia roboris } \\
\hline Hieracium murorum agg. (PQ, QFt, Qpp) & $\mathrm{C}$ & + & I & 4 & - & - & 0 & - & - & 0 & - & - & 0 \\
\hline Hieracium umbellatum agg. (PQ, Qpp, NA, Epa) & $\mathrm{C}$ & + & $\mathrm{I}$ & 4 & - & - & 0 & - & - & 0 & - & - & 0 \\
\hline Pteridium aquilinum (PQ) & $\mathrm{C}$ & - & - & 0 & - & - & 0 & - & - & 0 & + & II & 40 \\
\hline Veronica officinalis (PQ, NA, Epa) & $\mathrm{C}$ & - & - & 0 & + & I & 4 & - & - & 0 & + & II & 30 \\
\hline \multicolumn{14}{|l|}{ 1.4. Quercetea pubescentis-petraeae } \\
\hline Allium oleraceum (Fru) & $\mathrm{C}$ & + & I & 20 & + & II & 32 & - & - & 0 & - & - & 0 \\
\hline Asparagus officinalis (FBt) & $\mathrm{C}$ & + & I & 8 & - & - & 0 & - & - & 0 & - & - & 0 \\
\hline Astragalus glycyphyllos & $\mathrm{C}$ & + & $\mathrm{I}$ & 12 & + & I & 4 & + & I & 16 & + & I & 10 \\
\hline Berberis vulgaris (Pru) & $\mathrm{S}$ & + & II & 40 & + & II & 32 & - & - & 0 & - & - & 0 \\
\hline Buglossoides purpuro-coerulea (OCn, AQ) & $\mathrm{C}$ & + & $\mathrm{I}$ & 4 & +-2 & IV & 72 & - & - & 0 & - & - & 0 \\
\hline Carex michelii & $\mathrm{C}$ & + & I & 16 & + & I & 8 & - & - & 0 & - & - & 0 \\
\hline Clematis recta & $\mathrm{C}$ & - & - & 0 & + & I & 4 & - & - & 0 & - & - & 0 \\
\hline Clinopodium vulgare & $\mathrm{C}$ & + & I & 20 & + & III & 56 & + & II & 24 & - & - & 0 \\
\hline Cornus mas (OCn, Qc) & $\mathrm{S}$ & - & - & 0 & +-1 & I & 20 & +-1 & II & 28 & - & - & 0 \\
\hline Doronicum hungaricum (AQ) & $\mathrm{C}$ & + & I & 4 & - & - & 0 & - & - & 0 & - & - & 0 \\
\hline Euonymus verrucosus (Pru) & $\mathrm{S}$ & - & - & 0 & + & IV & 64 & - & - & 0 & + & I & 10 \\
\hline Fraxinus ornus $(\mathrm{OCn})$ & B1 & - & - & 0 & + & I & 8 & - & - & 0 & - & - & 0 \\
\hline Geranium divaricatum (GA) & $\mathrm{C}$ & + & I & 4 & - & - & 0 & - & - & 0 & - & - & 0 \\
\hline Hieracium sabaudum agg. (Qr) & $\mathrm{C}$ & + & $\mathrm{I}$ & 4 & + & I & 12 & - & - & 0 & + & I & 20 \\
\hline Hylotelephium telephium ssp. maximum & $\mathrm{C}$ & - & - & 0 & + & I & 4 & - & - & 0 & - & - & 0 \\
\hline Inula salicina (MoA, Fvg) & $\mathrm{C}$ & + & I & 4 & + & I & 4 & - & - & 0 & - & - & 0 \\
\hline Iris variegata (Fvl) & $\mathrm{C}$ & - & - & 0 & + & I & 4 & - & - & 0 & - & - & 0 \\
\hline Lactuca quercina ssp. quercina & $\mathrm{C}$ & + & I & 4 & - & - & 0 & - & - & 0 & - & - & 0 \\
\hline Lactuca quercina ssp. sagittata & $\mathrm{C}$ & - & - & 0 & - & - & 0 & + & I & 16 & - & - & 0 \\
\hline Lathyrus niger (Qc) & $\mathrm{C}$ & + & I & 8 & - & - & 0 & - & - & 0 & + & I & 10 \\
\hline Lithospermum officinale & $\mathrm{C}$ & + & I & 16 & + & I & 12 & - & - & 0 & - & - & 0 \\
\hline Lychnis coronaria & $\mathrm{C}$ & - & - & 0 & + & I & 4 & - & - & 0 & - & - & 0 \\
\hline Melittis melissophyllum ssp. carpatica (Qc) & $\mathrm{C}$ & - & - & 0 & + & I & 4 & - & - & 0 & - & - & 0 \\
\hline Orchis purpurea $(\mathrm{F}, \mathrm{OCn})$ & $\mathrm{C}$ & - & - & 0 & + & I & 4 & - & - & 0 & - & - & 0 \\
\hline Ornithogalum sphaerocarpum (Cp, Fru) & $\mathrm{C}$ & - & - & 0 & + & I & 4 & - & - & 0 & - & - & 0 \\
\hline Peucedanum cervaria (Fvl) & $\mathrm{C}$ & - & - & 0 & + & I & 4 & - & - & 0 & - & - & 0 \\
\hline Physalis alkekengi (Ulm) & $\mathrm{C}$ & - & - & 0 & + & I & 16 & - & - & 0 & - & - & 0 \\
\hline Piptatherum virescens (OCn, AQ) & $\mathrm{C}$ & + & I & 8 & + & II & 36 & - & - & 0 & - & - & 0 \\
\hline Polygonatum odoratum (Fvl) & $\mathrm{C}$ & +-1 & $\mathrm{I}$ & 20 & + & II & 24 & + & I & 4 & + & I & 10 \\
\hline Prunus spinosa (Pru, Prf) & $\mathrm{S}$ & +-2 & III & 56 & + & II & 36 & + & II & 24 & + & III & 50 \\
\hline Pulmonaria mollissima & $\mathrm{C}$ & - & - & 0 & +-1 & III & 48 & + & $\mathrm{I}$ & 20 & - & - & 0 \\
\hline Pyrus pyraster (Cp) & $\mathrm{S}$ & +-1 & III & 52 & +-1 & II & 36 & +-1 & III & 44 & + & II & 30 \\
\hline Quercus cerris (Qr, $\mathrm{PQ})$ & $\mathrm{S}$ & - & - & 0 & +-1 & II & 32 & +-1 & II & 24 & +-2 & $\mathrm{~V}$ & 100 \\
\hline Rosa canina agg. (Pru, Prf) & $\mathrm{S}$ & + & I & 16 & + & IV & 80 & + & I & 20 & + & I & 10 \\
\hline Silene viridiflora & $\mathrm{C}$ & - & - & 0 & - & - & 0 & - & - & 0 & + & I & 10 \\
\hline Thalictrum aquilegiifolium & $\mathrm{C}$ & - & - & 0 & + & I & 8 & - & - & 0 & - & - & 0 \\
\hline Viburnum lantana (QFt) & $\mathrm{S}$ & + & II & 28 & +-1 & IV & 72 & - & - & 0 & - & - & 0 \\
\hline Vincetoxicum hirundinaria (Fvl) & $\mathrm{C}$ & + & I & 4 & + & I & 16 & - & - & 0 & - & - & 0 \\
\hline Viola hirta & $\mathrm{C}$ & + & I & 12 & + & III & 44 & - & - & 0 & + & I & 10 \\
\hline 1.4.1. Quercetalia cerridis & & & & & & & & & & & & & \\
\hline Cerasus mahaleb & $\mathrm{S}$ & + & I & 4 & - & - & 0 & - & - & 0 & - & - & 0 \\
\hline Gagea pratensis (Sea) & $\mathrm{C}$ & - & - & 0 & - & - & 0 & + & I & 8 & - & - & 0 \\
\hline 1.4.1.1. Aceri tatarici-Quercion & & & & & & & & & & & & & \\
\hline Acer tataricum (Qpp) & $\mathrm{S}$ & +-3 & III & 44 & +-2 & IV & 68 & +-2 & IV & 80 & - & - & 0 \\
\hline Melica altissima & $\mathrm{C}$ & + & $\mathrm{I}$ & 8 & - & - & 0 & - & - & 0 & - & - & 0 \\
\hline
\end{tabular}


KEVEY (2021): A Duna-Tisza köze gyertyános-tölgyesei

\begin{tabular}{|c|c|c|c|c|c|c|c|c|c|c|c|c|c|}
\hline & \multirow{2}{*}{ Szint } & \multicolumn{3}{|c|}{ D-T } & \multicolumn{3}{|c|}{ Mf } & \multicolumn{3}{|c|}{ Ny } & \multicolumn{3}{|c|}{ Ba } \\
\hline & & A-D & $\mathbf{K}$ & $\mathbf{K} \%$ & A-D & $\mathbf{K}$ & $\mathbf{K} \%$ & A-D & $\mathbf{K}$ & $\mathbf{K} \%$ & A-D & $\mathbf{K}$ & $\mathbf{K} \%$ \\
\hline $\begin{array}{l}\text { 2. Cypero-Phragmitea } \\
\text { 2.1. Phragmitetea }\end{array}$ & & & & & & & & & & & & & \\
\hline Carex acutiformis (Mag, Cgr, Moa, Sal, Ata) & $\mathrm{C}$ & + & $\mathrm{I}$ & 12 & - & - & 0 & - & - & 0 & - & - & 0 \\
\hline Eupatorium cannabinum (Epa, Sal, Ata, Ai) & $\mathrm{C}$ & - & - & 0 & + & $\mathrm{I}$ & 4 & - & - & 0 & - & - & 0 \\
\hline Phragmites australis (Moa, FPe, Spu, Ata) & $\mathrm{C}$ & + & I & 4 & - & - & 0 & - & - & 0 & - & - & 0 \\
\hline $\begin{array}{l}\text { Solanum dulcamara }(\mathrm{Cn}, \mathrm{Bia}, \mathrm{Spu}) \\
\text { 2.1.1. Magnocaricetalia } \\
\text { 2.1.1.1. Magnocaricion } \\
\text { 2.1.1.1. Caricenion gracilis }\end{array}$ & $\mathrm{C}$ & + & I & 8 & - & - & 0 & - & - & 0 & + & I & 10 \\
\hline $\begin{array}{l}\text { Carex acuta (Pte, Mag, Moa, Ata, Ai) } \\
\text { 3. Molinio-Arrhenatherea }\end{array}$ & $\mathrm{C}$ & + & $\mathrm{I}$ & 4 & - & - & 0 & - & - & 0 & - & - & 0 \\
\hline Colchicum autumnale (Moa) & $\mathrm{C}$ & + & II & 24 & - & - & 0 & + & I & 12 & - & - & 0 \\
\hline $\begin{array}{l}\text { Poa trivialis (Pte, Spu, Ata, Ai) } \\
\text { 3.1. Molinio-Juncetea }\end{array}$ & $\mathrm{C}$ & + & $\mathrm{I}$ & 8 & - & - & 0 & - & - & 0 & - & - & 0 \\
\hline Deschampsia caespitosa (Des, Sal, Ata, Ai) & $\mathrm{C}$ & + & II & 32 & + & II & 36 & + & I & 20 & + & I & 10 \\
\hline Symphytum officinale (Pte, $\mathrm{Cn}, \mathrm{Spu}, \mathrm{Ata}, \mathrm{Ai})$ & $\mathrm{C}$ & +-1 & I & 12 & - & - & 0 & - & - & 0 & - & - & 0 \\
\hline $\begin{array}{l}\text { Veratrum album (Ata, Ai) } \\
\text { 3.1.1. Molinietalia coeruleae }\end{array}$ & $\mathrm{C}$ & + & I & 4 & + & I & 4 & - & - & 0 & - & - & 0 \\
\hline Angelica sylvestris (Mag, Ata, Ai) & $\mathrm{C}$ & + & II & 36 & + & $\mathrm{I}$ & 8 & - & - & 0 & - & - & 0 \\
\hline $\begin{array}{l}\text { Valeriana officinalis (Mag, } \mathrm{FiC} \text { ) } \\
\text { 3.1.1.1. Deschampsion caespitosae }\end{array}$ & $\mathrm{C}$ & - & - & 0 & + & $\mathrm{I}$ & 4 & - & - & 0 & - & - & 0 \\
\hline $\begin{array}{l}\text { Galium rubioides (Alo, Qpp) } \\
\text { 3.2. Nardo-Callunetea } \\
\text { 3.2.1. Nardetalia } \\
\text { 3.2.1.1. Nardo-Agrostion tenuis }\end{array}$ & $\mathrm{C}$ & + & I & 8 & - & - & 0 & - & - & 0 & - & - & 0 \\
\hline $\begin{array}{l}\text { Botrychium lunaria }(\mathrm{BrF}) \\
\text { 3.3. Calluno-Ulicetea } \\
\text { 3.3.1. Vaccinio-Genistetalia } \\
\text { 3.3.1.1. Calluno-Genistion }\end{array}$ & $\mathrm{C}$ & + & I & 4 & - & - & 0 & - & - & 0 & - & - & 0 \\
\hline $\begin{array}{l}\text { Betula pendula }(\mathrm{Qr}, \mathrm{APa}) \\
\text { 4. Festuco-Bromea } \\
\text { 4.1. Festucetea vaginatae } \\
\text { 4.1.1. Festucetalia vaginatae } \\
\text { 4.1.1.1. Festucion vaginatae }\end{array}$ & S & 1 & $\mathrm{I}$ & 4 & +-2 & II & 40 & + & I & 16 & - & - & 0 \\
\hline $\begin{array}{l}\text { Equisetum ramosissimum (TrE, CyF) } \\
\text { 4.2. Festuco-Brometea }\end{array}$ & $\mathrm{C}$ & - & - & 0 & + & $\mathrm{I}$ & 4 & - & - & 0 & - & - & 0 \\
\hline Arabis hirsuta (Qpp) & $\mathrm{C}$ & + & I & 8 & + & $\mathrm{I}$ & 4 & - & - & 0 & - & - & 0 \\
\hline Brachypodium pinnatum (Qpp) & $\mathrm{C}$ & + & $\mathrm{I}$ & 4 & - & - & 0 & - & - & 0 & - & - & 0 \\
\hline $\begin{array}{l}\text { Muscari racemosum (Qpp) } \\
\text { 4.2.1. Festucetalia valesiacae } \\
\text { 4.2.1.1. Festucion rupicolae }\end{array}$ & $\mathrm{C}$ & + & $\mathrm{I}$ & 8 & + & $\mathrm{I}$ & 8 & - & - & 0 & - & - & 0 \\
\hline $\begin{array}{l}\text { Cynoglossum hungaricum (Qpp) } \\
\text { 4.2.1.1.1. Cynodonto-Festucenion }\end{array}$ & $\mathrm{C}$ & + & $\mathrm{I}$ & 12 & + & $\mathrm{I}$ & 4 & - & - & 0 & - & - & 0 \\
\hline $\begin{array}{l}\text { Cerinthe minor (Sea) } \\
\text { 5. Chenopodio-Scleranthea }\end{array}$ & $\mathrm{C}$ & - & - & 0 & + & $\mathrm{I}$ & 4 & - & - & 0 & - & - & 0 \\
\hline Bromus sterilis (Che) & $\mathrm{C}$ & +-1 & II & 24 & + & I & 4 & - & - & 0 & - & - & 0 \\
\hline Cannabis sativa & $\mathrm{C}$ & + & I & 8 & + & I & 4 & - & - & 0 & - & - & 0 \\
\hline Fumaria schleicheri (Che, Pla) & $\mathrm{C}$ & + & I & 4 & - & - & 0 & - & - & 0 & - & - & 0 \\
\hline $\begin{array}{l}\text { Solanum nigrum (Che) } \\
\text { 5.1. Secalietea }\end{array}$ & $\mathrm{C}$ & + & I & 4 & + & I & 4 & - & - & 0 & - & - & 0 \\
\hline Lamium purpureum (Che) & $\mathrm{C}$ & + & $\mathrm{I}$ & 12 & - & - & 0 & + & I & 4 & - & - & 0 \\
\hline Muscari comosum (FBt) & $\mathrm{C}$ & + & $\mathrm{I}$ & 20 & + & I & 16 & + & I & 4 & - & - & 0 \\
\hline Silene alba (Cau, GA) & $\mathrm{C}$ & + & I & 4 & - & - & 0 & - & - & 0 & - & - & 0 \\
\hline $\begin{array}{l}\text { Silene noctiflora }(\mathrm{Cau}, \mathrm{GA}) \\
\text { 5.2. Chenopodietea }\end{array}$ & $\mathrm{C}$ & - & - & 0 & + & $\mathrm{I}$ & 8 & - & - & 0 & - & - & 0 \\
\hline Arctium lappa (Arc, Pla, Spu) & $\mathrm{C}$ & + & I & 4 & + & I & 12 & - & - & 0 & - & - & 0 \\
\hline Arctium minus (Arc, Bia, Pla) & $\mathrm{C}$ & + & III & 52 & + & II & 32 & + & III & 48 & + & II & 40 \\
\hline Ballota nigra (Arc) & $\mathrm{C}$ & + & II & 28 & - & - & 0 & + & $\mathrm{I}$ & 4 & - & - & 0 \\
\hline Leonurus cardiaca (Arc) & $\mathrm{C}$ & + & $\mathrm{I}$ & 12 & - & - & 0 & + & $\mathrm{I}$ & 4 & - & - & 0 \\
\hline
\end{tabular}


Kitaibelia 26(1): 49-76.

\begin{tabular}{|c|c|c|c|c|c|c|c|c|c|c|c|c|c|}
\hline & \multirow{2}{*}{ Szint } & \multicolumn{3}{|c|}{ D-T } & \multicolumn{3}{|c|}{ Mf } & \multicolumn{3}{|c|}{$\mathrm{Ny}$} & \multicolumn{3}{|c|}{ Ba } \\
\hline & & A-D & $\mathbf{K}$ & $\mathbf{K} \%$ & A-D & $\mathbf{K}$ & $\mathbf{K} \%$ & A-D & $\mathbf{K}$ & $\mathbf{K} \%$ & A-D & $\mathbf{K}$ & $\mathbf{K} \%$ \\
\hline $\begin{array}{l}\text { 5.3. Galio-Urticetea } \\
\text { 5.3.1. Calystegietalia sepium } \\
\text { 5.3.1.1. Galio-Alliarion }\end{array}$ & & & & & & & & & & & & & \\
\hline Aethusa cynapium (Che) & $\mathrm{C}$ & - & - & 0 & - & - & 0 & + & $\mathrm{I}$ & 8 & + & I & 10 \\
\hline Alliaria petiolata (Epa) & $\mathrm{C}$ & +-1 & V & 88 & + & $\mathrm{V}$ & 84 & +-1 & V & 96 & + & V & 90 \\
\hline Chaerophyllum temulum & $\mathrm{C}$ & + & II & 40 & +-1 & $\mathrm{~V}$ & 88 & +-1 & V & 88 & + & II & 30 \\
\hline $\begin{array}{l}\text { Parietaria officinalis (Cn, TA) } \\
\text { 5.3.1.2. Calystegion sepium }\end{array}$ & $\mathrm{C}$ & + & I & 4 & + & I & 4 & - & - & 0 & + & II & 30 \\
\hline Chaerophyllum bulbosum & $\mathrm{C}$ & + & I & 4 & - & - & 0 & - & - & 0 & - & - & 0 \\
\hline Lamium maculatum (Pna, Agi, TA) & $\mathrm{C}$ & - & - & 0 & 2 & I & 4 & + & I & 4 & + & I & 20 \\
\hline $\begin{array}{l}\text { Myosoton aquaticum (Pte, } \mathrm{Spu}, \mathrm{Ata}, \mathrm{Ai}) \\
\text { 5.4. Epilobietea angustifolii } \\
\text { 5.4.1. Epilobietalia }\end{array}$ & $\mathrm{C}$ & - & - & 0 & + & I & 4 & - & - & 0 & - & - & 0 \\
\hline Galeopsis bifida $(\mathrm{Cn})$ & $\mathrm{C}$ & + & I & 4 & - & - & 0 & + & II & 28 & + & I & 10 \\
\hline $\begin{array}{l}\text { Salix caprea }(\mathrm{SaS}, \mathrm{QFt}) \\
6 \text {. Indifferens }\end{array}$ & $\mathrm{A} 2$ & - & - & 0 & - & - & 0 & + & I & 8 & - & - & 0 \\
\hline Ajuga genevensis (Ara, FBt, Qpp) & $\mathrm{C}$ & + & I & 4 & - & - & 0 & - & - & 0 & - & - & 0 \\
\hline Allium scorodoprasum (Qpp, Sea, Che) & $\mathrm{C}$ & + & II & 36 & + & I & 12 & - & - & 0 & + & I & 10 \\
\hline Anthriscus cerefolium (Arc, GA) & $\mathrm{C}$ & +-2 & III & 44 & + & II & 32 & + & I & 4 & + & I & 10 \\
\hline Calamagrostis epigeios (Moa, Fvg, Epa) & $\mathrm{C}$ & + & I & 8 & - & - & 0 & - & - & 0 & - & - & 0 \\
\hline Carex flacca (Mag, Moa, Arn, FBt, Qpp) & $\mathrm{C}$ & +-1 & I & 20 & - & - & 0 & - & - & 0 & - & - & 0 \\
\hline Carex hirta (Pte, MoA, Pla) & $\mathrm{C}$ & - & - & 0 & + & I & 4 & - & - & 0 & - & - & 0 \\
\hline Chelidonium majus (Che, Arc, GA, Epa) & $\mathrm{C}$ & +-2 & I & 20 & + & III & 44 & + & III & 52 & + & II & 40 \\
\hline Cruciata laevipes (Arn, Fru, Arc, Cia, Qpp) & $\mathrm{C}$ & - & - & 0 & - & - & 0 & + & I & 4 & - & - & 0 \\
\hline Equisetum arvense (MoA, Sea, Sal, Ata, Ai) & $\mathrm{C}$ & + & I & 8 & - & - & 0 & + & I & 4 & + & I & 10 \\
\hline Galium aparine (Sea, Epa, QFt) & $\mathrm{C}$ & +-1 & V & 84 & +-1 & $\mathrm{~V}$ & 92 & +-1 & $\mathrm{~V}$ & 84 & + & V & 90 \\
\hline Galium mollugo (MoA, FBt, Qrp, Qpp) & $\mathrm{C}$ & + & I & 12 & + & II & 40 & - & - & 0 & - & - & 0 \\
\hline Glechoma hederacea (MoA, QFt, Sal, Ai) & $\mathrm{C}$ & - & - & 0 & + & I & 16 & + & II & 28 & + & I & 10 \\
\hline Juniperus communis (NA, Fvg, Qpp, EPn) & $\mathrm{S}$ & + & I & 16 & - & - & 0 & - & - & 0 & - & - & 0 \\
\hline Luzula campestris (NA, Moa, Ara, Qrp, Qpp) & $\mathrm{C}$ & - & - & 0 & + & I & 4 & - & - & 0 & - & - & 0 \\
\hline Lysimachia nummularia (Pte, Moa, Bia) & $\mathrm{C}$ & + & I & 8 & + & I & 12 & + & II & 32 & + & I & 20 \\
\hline Lythrum salicaria (Pte, Moa, Bia, Spu, Ata) & $\mathrm{C}$ & - & - & 0 & + & I & 4 & - & - & 0 & - & - & 0 \\
\hline Ornithogalum boucheanum (Sea, Arc, Qpp) & $\mathrm{C}$ & + & I & 8 & + & I & 20 & + & I & 8 & + & I & 10 \\
\hline Ornithogalum umbellatum (Ara, FBt, Sea) & $\mathrm{C}$ & + & II & 24 & + & II & 36 & + & I & 8 & + & III & 50 \\
\hline Pimpinella saxifraga (MoA, FB, Qpp) & $\mathrm{C}$ & + & I & 4 & - & - & 0 & - & - & 0 & - & - & 0 \\
\hline Poa bulbosa (FPe, FB, Sea, Che) & $\mathrm{C}$ & + & I & 4 & - & - & 0 & - & - & 0 & - & - & 0 \\
\hline Prunella vulgaris (Pte, MoA, ChS, QFt) & $\mathrm{C}$ & - & - & 0 & - & - & 0 & + & I & 4 & - & - & 0 \\
\hline Ranunculus repens (Pte, MoA, ChS, Spu, Ata) & $\mathrm{C}$ & + & I & 4 & - & - & 0 & - & - & 0 & - & - & 0 \\
\hline Rubus caesius (Spu) & S & +-1 & IV & 64 & + & III & 48 & + & III & 52 & +-1 & III & 50 \\
\hline Rubus fruticosus agg. (QFt, Epa, SaS) & B2 & - & - & 0 & - & - & 0 & - & - & 0 & + & I & 10 \\
\hline Sambucus nigra (Epa, SaS, QFt) & $\mathrm{S}$ & +-2 & V & 84 & +-2 & IV & 76 & +-1 & III & 60 & + & V & 100 \\
\hline Securigea varia (Ara, FBt, Qpp) & $\mathrm{C}$ & + & I & 4 & - & - & 0 & - & - & 0 & - & - & 0 \\
\hline Serratula tinctoria (MoA, Moa, Qrp, Qpp, PQ) & $\mathrm{C}$ & + & I & 4 & + & I & 8 & - & - & 0 & - & - & 0 \\
\hline Stellaria media (ChS, QFt, Spu) & $\mathrm{C}$ & +-1 & IV & 72 & + & I & 20 & +-1 & III & 44 & + & I & 20 \\
\hline Taraxacum officinale agg. (MoA, ChS) & $\mathrm{C}$ & + & I & 16 & - & - & 0 & + & I & 12 & - & - & 0 \\
\hline Torilis japonica (Arc, GA, Epa, QFt) & $\mathrm{C}$ & + & II & 32 & + & II & 36 & + & II & 40 & + & II & 30 \\
\hline $\begin{array}{l}\text { Urtica dioica (Arc, GA, Epa, Spu) } \\
\text { 7. Adventiva }\end{array}$ & $\mathrm{C}$ & + & III & 44 & +-1 & IV & 76 & +-1 & $\mathrm{~V}$ & 84 & + & IV & 80 \\
\hline Acer negundo & S & + & I & 8 & 1 & I & 4 & + & I & 8 & - & - & 0 \\
\hline Aesculus hippocastanum & S & + & I & 4 & - & - & 0 & - & - & 0 & - & - & 0 \\
\hline Ailanthus altissima & S & +-1 & I & 16 & +-1 & I & 16 & - & - & 0 & - & - & 0 \\
\hline Asclepias syriaca & $\mathrm{C}$ & + & $\mathrm{I}$ & 8 & - & - & 0 & - & - & 0 & - & - & 0 \\
\hline Celtis occidentalis & $S$ & +-3 & IV & 68 & +-1 & III & 56 & + & I & 4 & - & - & 0 \\
\hline Fraxinus pennsylvanica & S & +-2 & I & 16 & + & I & 8 & +-1 & I & 12 & - & - & 0 \\
\hline Gleditsia triacanthos & B2 & + & I & 8 & + & I & 12 & - & - & 0 & - & - & 0 \\
\hline Impatiens parviflora & $\mathrm{C}$ & + & $\mathrm{I}$ & 8 & - & - & 0 & - & - & 0 & - & - & 0 \\
\hline Juglans nigra & $S$ & + & I & 4 & + & I & 4 & - & - & 0 & - & - & 0 \\
\hline Morus alba & S & + & $\mathrm{I}$ & 8 & - & - & 0 & - & - & 0 & - & - & 0 \\
\hline Padus serotina & $S$ & +-1 & II & 24 & + & I & 12 & + & I & 4 & - & - & 0 \\
\hline Parthenocissus quinquefolia & B2 & - & - & 0 & - & - & 0 & + & $\mathrm{I}$ & 12 & - & - & 0 \\
\hline Phytolacca americana & $\mathrm{C}$ & + & $\mathrm{I}$ & 4 & +-1 & $\mathrm{I}$ & 8 & - & - & 0 & + & $\mathrm{I}$ & 10 \\
\hline
\end{tabular}


KEVEY (2021): A Duna-Tisza köze gyertyános-tölgyesei

\begin{tabular}{|c|c|c|c|c|c|c|c|c|c|c|c|c|c|}
\hline & \multirow{2}{*}{ Szint } & \multicolumn{3}{|c|}{ D-T } & \multicolumn{3}{|c|}{ Mf } & \multicolumn{3}{|c|}{ Ny } & \multicolumn{3}{|c|}{$\mathbf{B a}$} \\
\hline & & A-D & $\mathbf{K}$ & $\mathbf{K} \%$ & A-D & $\mathbf{K}$ & $\mathbf{K} \%$ & A-D & $\mathbf{K}$ & $\mathbf{K} \%$ & A-D & $\mathbf{K}$ & $\mathbf{K} \%$ \\
\hline Pinus sylvestris & $S$ & - & - & 0 & + & I & 4 & - & - & 0 & - & - & 0 \\
\hline Quercus rubra & B2 & + & I & 8 & - & - & 0 & + & II & 24 & + & I & 10 \\
\hline Robinia pseudo-acacia & $\mathrm{S}$ & +-2 & III & 52 & +-1 & III & 56 & +-1 & II & 32 & - & - & 0 \\
\hline Solidago canadensis & $\mathrm{C}$ & + & I & 16 & - & - & 0 & - & - & 0 & - & - & 0 \\
\hline Solidago gigantea ssp. serotina & $\mathrm{C}$ & + & I & 8 & + & I & 4 & + & I & 4 & + & I & 10 \\
\hline Stenactis annua & $\mathrm{C}$ & - & - & 0 & + & I & 4 & + & I & 4 & - & - & 0 \\
\hline Syringa vulgaris & $\mathrm{B} 2$ & + & $\mathrm{I}$ & 4 & - & - & 0 & - & - & 0 & - & - & 0 \\
\hline
\end{tabular}

5. táblázat Karakterfajok aránya

Table 5 Percentage of characteristic species

D-T: Duna-Tisza köze (KEVEY ined.: 25 felv.)

Mf: Mezőföld (KeVEY \& LendVAi 2015: 25 felv.)

Ny: Nyírség (KeveY et al. 2017: 25 felv.)

Ba: Bakonyalja (Kevey 2014: 10 felv.)

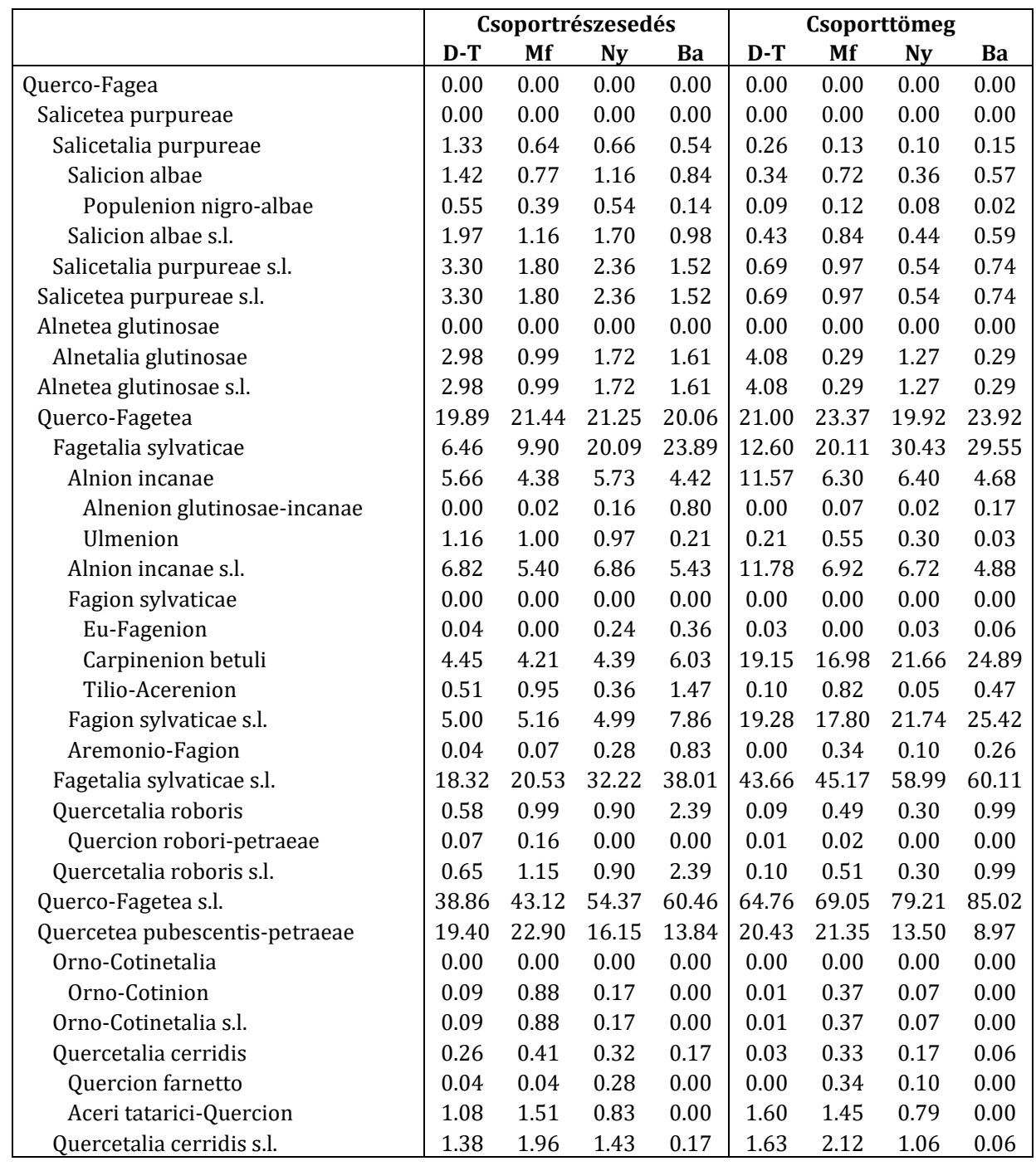


Kitaibelia 26(1): 49-76.

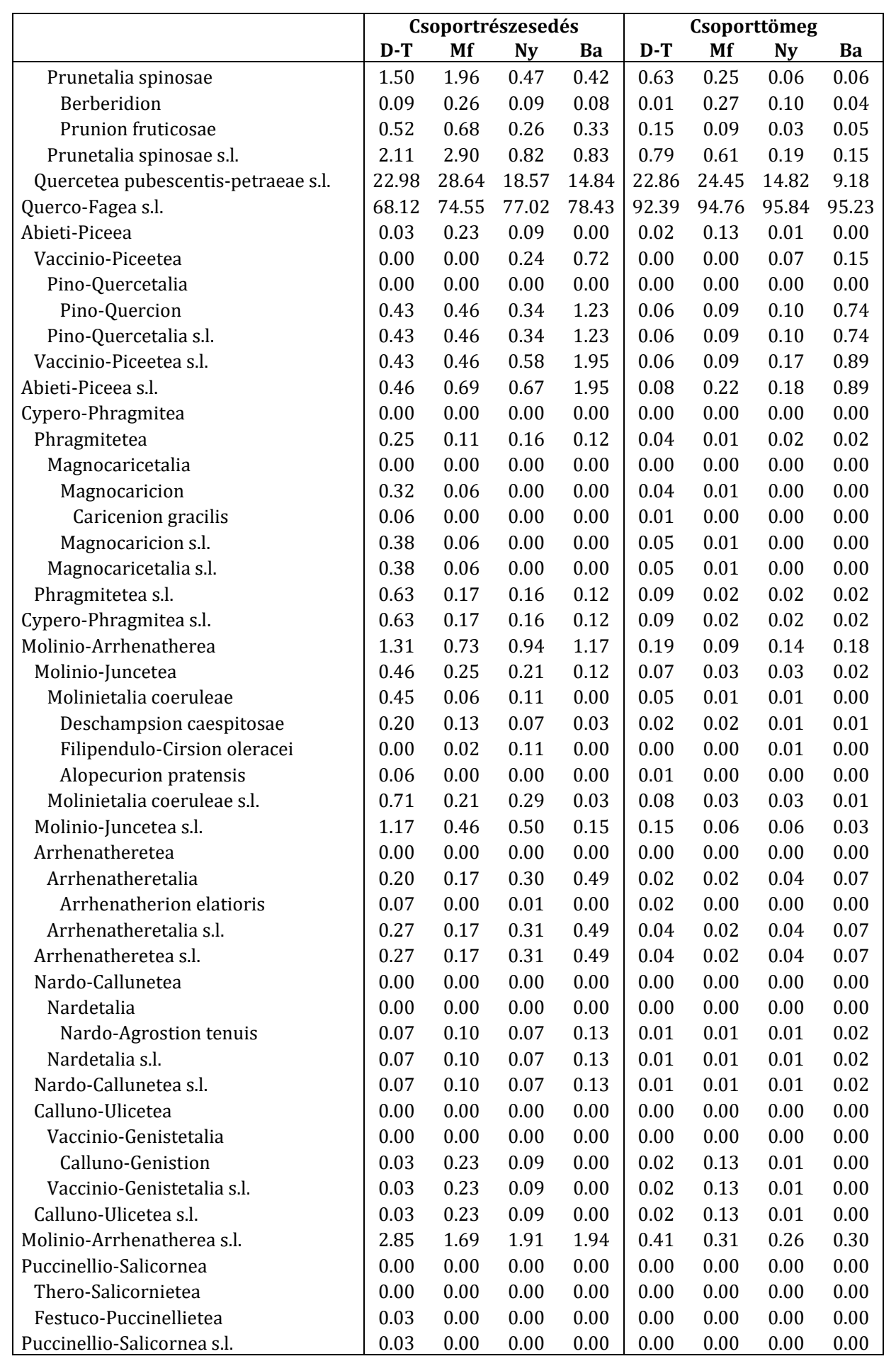


KEVEY (2021): A Duna-Tisza köze gyertyános-tölgyesei

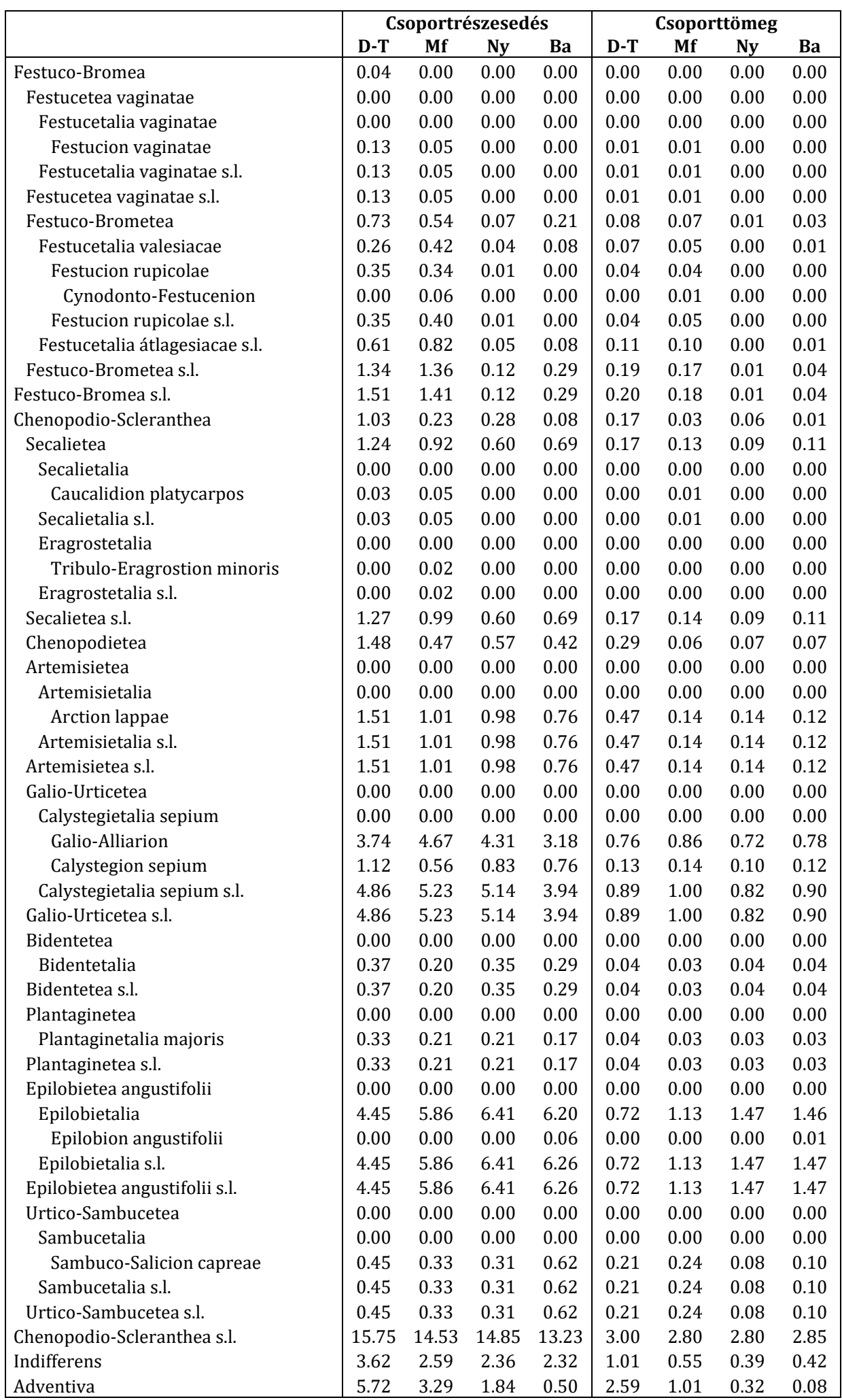


6. táblázat Szociális magatartási típusok aránya

Table 6 Percentage of social behaviour types (SBT)

D-T: Duna-Tisza köze (KEvEY ined.: 25 felv.)

Mf: Mezőföld (KevEy \& LENDVAI 2015: 25 felv.)

Ny: Nyírség (Kevey et al. 2017: 25 felv.)

Ba: Bakonyalja (KeVEY 2014: 10 felv.)

\begin{tabular}{|c|c|c|c|c|c|c|c|c|}
\hline & \multicolumn{4}{|c|}{ Csoportrészesedés } & \multicolumn{4}{|c|}{ Csoporttömeg } \\
\hline & D-T & Mf & $\mathrm{Ny}$ & $\mathrm{Ba}$ & D-T & Mf & $\mathrm{Ny}$ & Ba \\
\hline S 6 & 4,86 & 5,95 & 6,09 & 6,99 & 3,31 & 2,46 & 2,84 & 2,08 \\
\hline C 5 & 11,87 & 11,55 & 12,26 & 13,81 & 57,07 & 52,25 & 62,50 & 70,38 \\
\hline G 4 & 45,67 & 51,19 & 53,15 & 52,58 & 30,52 & 38,14 & 29,41 & 21,56 \\
\hline NP 3 & 0,17 & 0,00 & 0,00 & 0,00 & 0,02 & 0,00 & 0,00 & 0,00 \\
\hline DT 2 & 22,88 & 22,20 & 22,11 & 22,30 & 3,53 & 5,25 & 4,23 & 5,31 \\
\hline W 1 & 7,54 & 5,67 & 4,32 & 3,66 & 2,73 & 0,87 & 0,68 & 0,56 \\
\hline I -1 & 2,51 & 1,47 & 0,71 & 0,17 & 1,69 & 0,28 & 0,13 & 0,03 \\
\hline A -1 & 0,17 & 0,07 & 0,21 & 0,00 & 0,02 & 0,01 & 0,03 & 0,00 \\
\hline RC -2 & 1,04 & 0,07 & 0,21 & 0,00 & 0,21 & 0,01 & 0,03 & 0,00 \\
\hline AC - 3 & 3,21 & 1,82 & 0,92 & 0,33 & 0,90 & 0,73 & 0,16 & 0,05 \\
\hline Val & 3,11 & 3,41 & 3,55 & 3,69 & 4,32 & 4,37 & 4,56 & 4,62 \\
\hline
\end{tabular}

